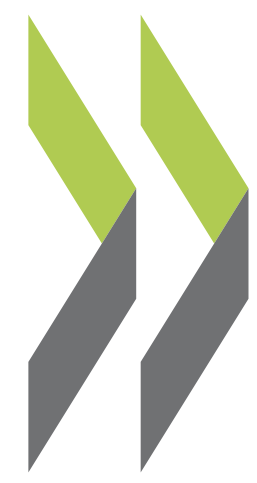

OECD Economics Department Working Papers No. 334

\section{The Economic}

Consequences of Terrorism
Patrick Lenain,

Marcos Bonturi,

Vincent Koen 
Organisation de Coopération et de Développement Economiques

Organisation for Economic Co-operation and Development

17-Jul-2002

ECONOMICS DEPARTMENT

English text only

THE ECONOMIC CONSEQUENCES OF TERRORISM

ECONOMICS DEPARTMENT WORKING PAPERS No. 334

by

Patrick Lenain, Marcos Bonturi and Vincent Koen

All Economics Department Working Papers are now available through OECD's Internet Web site at http://www.oecd.org/eco 


\section{ABSTRACT/RÉSUMÉ}

\section{The economic consequences of terrorism}

The unprecedented 11 September 2001 terrorist attacks in the United States caused massive casualties and damage, and ushered in an era of greater uncertainty. While a prompt and vigorous policy response helped limit the immediate economic impact of the aggression, the heightened terrorist threat has some long-lasting, if diffuse, macroeconomic repercussions. Three channels of influence are explored in this paper: shrinking insurance coverage stemming from the perception of greater risk, higher trade costs possibly affecting international trade, and stepped-up security spending partially rolling back the "peace dividend" of the 1990s. It is argued that, in the absence of new large-scale terrorist attacks, and provided terrorism risk is dealt with efficiently, the net long-run macroeconomic impact is probably tangible but limited.

JEL Code: D23, D81, E23, E32, E58, E65, F19, F22, G14, H56, L83, L91, L98, O49

Keywords: Terrorism, uncertainty, monetary policy, fiscal policy, insurance, transport, security, defence

******

\section{Les conséquences économiques du terrorisme}

Les attentats sans précédent du 11 septembre 2001 aux États-Unis ont causé des pertes humaines et des dégâts matériels énormes, et ont inauguré une ère de plus grande incertitude. $\mathrm{Si}$ une réponse rapide et vigoureuse des responsables a aidé à limiter l'impact économique immédiat de l'agression, le renforcement de la menace terroriste a des répercussions macroéconomiques durables, quoique diffuses. Trois canaux d'influence sont examinés dans la présente étude : une couverture d'assurance réduite résultant de la perception de risque plus important, des coûts de transaction plus élevés pouvant affecter le commerce international, et une augmentation des dépenses de sécurité renversant partiellement le « dividende de la paix » des années 90. Il en ressort qu'en l'absence de nouvelles attaques de grande ampleur, et à condition que le risque terroriste soit géré efficacement, l'impact macroéconomique net à long terme est probablement tangible mais limité.

Classification JEL: D23, D81, E23, E32, E58, E65, F19, F22, G14, H56, L83, L91, L98, O49

Mots-clés: terrorisme, incertitude, politique monétaire, politique budgétaire, assurance, transport, sécurité, défense

\section{Copyright: OECD 2002}

Applications for permission to reproduce or translate all, or part of, this material should be made to: Head of Publications Service, OECD, 2 rue André-Pascal, 75775 PARIS CEDEX 16, Paris. 
Table of contents

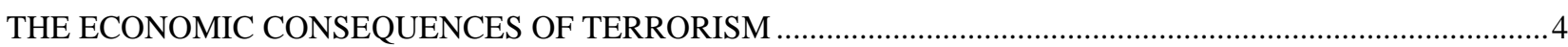

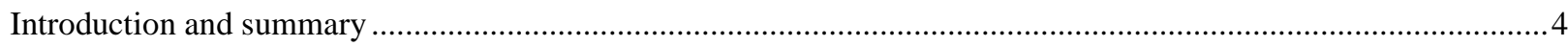

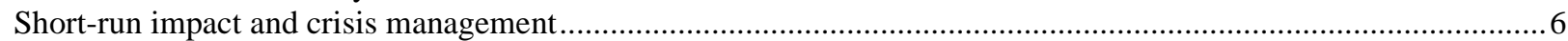

The adverse conjunctural impact was sharp but temporary.....................................................................

Large temporary liquidity injections by the Federal Reserve safeguarded the financial system ........................13

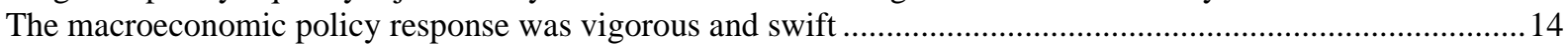

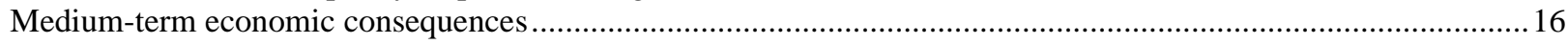

The shrinkage of affordable insurance coverage: should governments intervene? ........................................17

Increased shipping costs: is there a trade-off between efficiency and security? .............................................23

The impact of growing security and military spending: has the "peace dividend" been reversed? ......................28

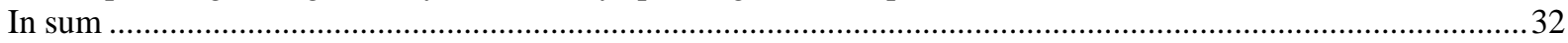

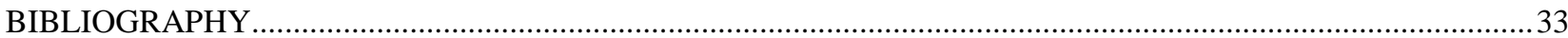

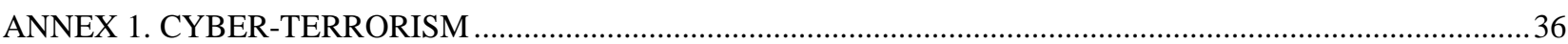

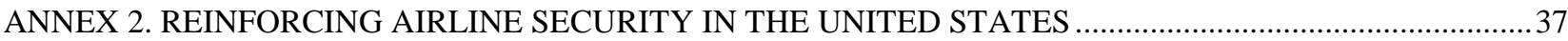

Boxes

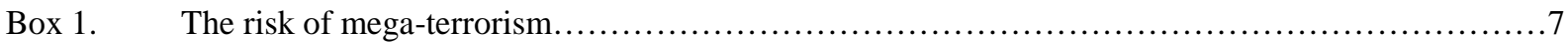

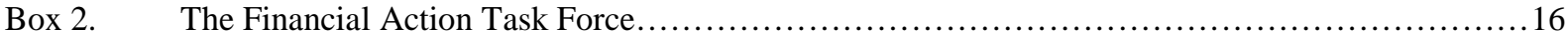

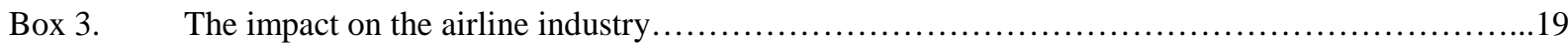

Box 4. State mechanisms to provide insurance or reinsurance against terrorism risk...................22

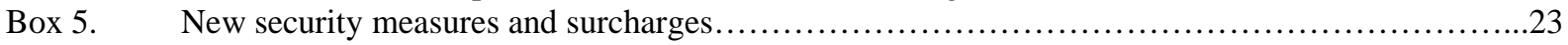

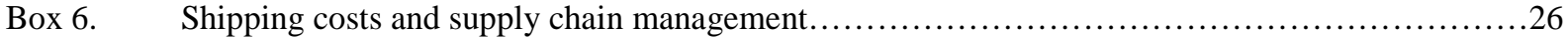

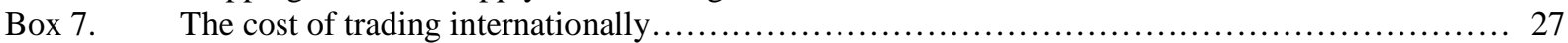

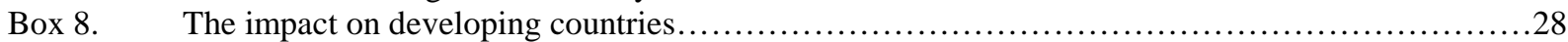

Tables

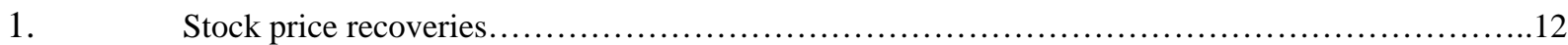

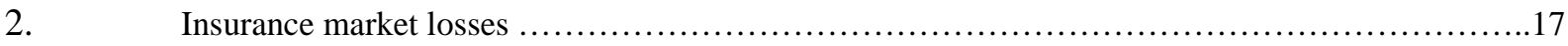

3. Fiscal support to domestic demand in the aftermath of selected catastrophes....................29

4. Spending on defence and police in selected countries....................................... 30

A1.1 Estimated worldwide economic impact of malicious code attacks.............................36

Figures

1.

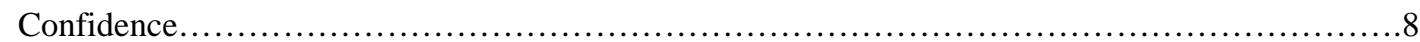

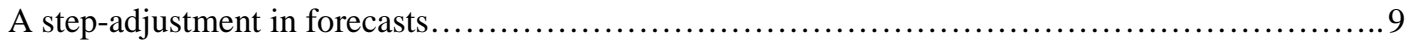

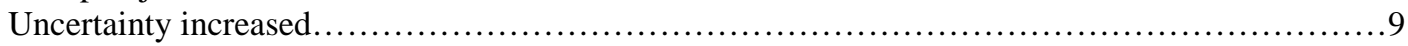

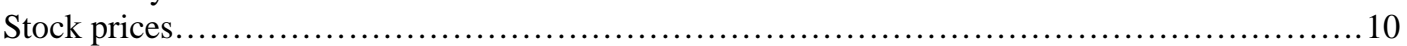

Credit spread between corporate and government benchmark bonds............................ 11

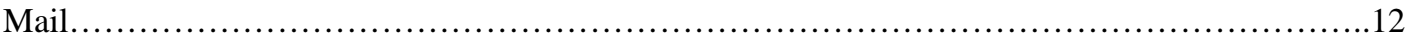

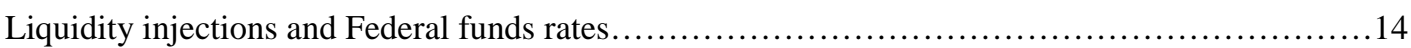

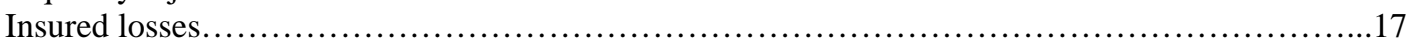

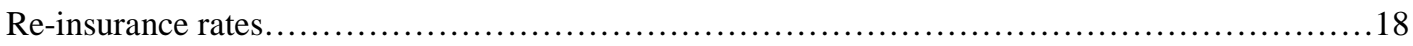

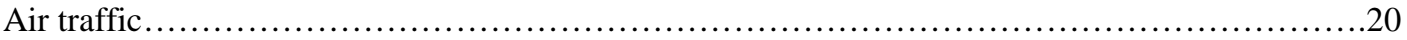

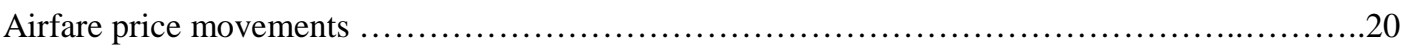

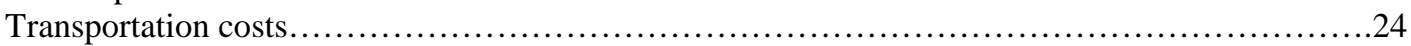

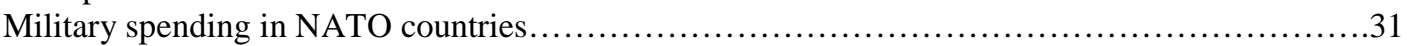




\title{
THE ECONOMIC CONSEQUENCES OF TERRORISM ${ }^{1}$
}

\author{
Patrick Lenain, Marcos Bonturi, Vincent Koen
}

\section{Introduction and summary}

1. On the morning of Tuesday 11 September 2001, the United States was hit by a set of unprecedented terrorist attacks, calculated to inflict massive civilian casualties and damage. Four hijacked commercial jets crashed, two into the World Trade Center towers in Manhattan, which collapsed shortly thereafter, one on the Pentagon in Washington DC, and the last one in Pennsylvania. Over 3000 people were killed, including hundreds of rescue personnel. The US President declared the aggression to be an act of war and in early October military action commenced in Afghanistan, which harboured the al-Qaeda terrorist network responsible for the attacks. This was presented as the first phase of a broader and likely drawn-out war against global terrorism, in which the United States were joined by NATO and many other countries. Even though this was not the first attack in the United States, the horrific scale of destruction and the boldness of the terrorists ushered in a period of greater uncertainty. ${ }^{2} \mathrm{~A}$ few months later, however, the direct economic effects seemed to have largely vanished. The Taliban regime in Afghanistan tumbled in a matter of weeks. Confidence and equity prices bounced back rapidly. Consumption and activity showed more resilience than initially feared, not least thanks to a vigorous response by policymakers and the private sector. Even though the short-term macroeconomic impact has largely dissipated, the attacks and the response they have elicited may still have long-lasting implications. In addition, further terrorist attacks remain a prominent danger, as several subsequent thwarted attempts testify. ${ }^{3}$

2. This paper analyses the economic consequences of terrorism, both in terms of immediate policy response in the aftermath of the attacks and of medium-term policy implications for regulatory, trade and

1. This paper was originally written at the request of the OECD Economic Policy Committee, which discussed an earlier version at its April 2002 meeting. The three authors work for the Economics Department of the OECD. Patrick Lenain and Marcos Bonturi are in the office of the Head of Department, and Vincent Koen is a senior economist in the General Economic Assessment Division. The paper benefited from helpful discussions with officials of various government agencies as well as experts of the private sector, national research organisations, various academic institutions and international financial organisations. The authors are grateful for helpful comments and suggestions made by Ignazio Visco and other OECD colleagues. Special thanks also go to Peter Downes for having undertaken the Interlink simulation, Sandra Wilson for having organised contacts in the United States, Debra Bloch for her skilled research assistance and Susan Gascard for technical preparation of the document.

2. Uncertainty is to be understood here as risk to which probabilities are hard to assign, along the lines of the classic distinction made by Knight (1921).

3. Examples include the discovery, in an Italian port, of an al-Quaeda suspect inside a container bound for Canada, complete with food and telecommunications equipment. Another near-miss was the attempt by a passenger on a transatlantic flight to set off explosive material fitted in his shoes. 
fiscal policy. The first section covers the short-term impact of the attacks and the crisis management decisions taken by the authorities to limit or offset their direct negative economic impact. The second section looks at the reaction of the insurance industry to the increased threat of terrorism and discusses whether governments should intervene when the private insurance sector fails to cover terrorism. The third section examines the impediments to international trade that could result from tighter security screenings of border crossings. The fourth section discusses the rise in national defence and domestic security spending, which may divert resources away from directly productive uses and contribute to a deterioration of the fiscal outlook.

3. A first main message of this paper is that the vigorous policy response after the attacks has played a very important role in averting a short-term negative economic impact. A second message is that medium-term policies aimed at enhancing protection against the threat of terrorism need to be properly designed. This has several policy implications:

- Crisis management played a key role after 11 September to restore confidence, safeguard the financial system and avoid a self-fulfilling depression. Decisions taken by the Federal Reserve, other central banks and governments were essential in this respect. One lesson of this crisis is that when policymakers have to take rapid decisions in an environment of deep uncertainty and imperfect information, priority ought to be given to liquidity management. Financial support to any sector or industry should focus on short-term loans or guarantees, rather than on grants or other direct budget outlays. After the immediate crisis response, more attention can be devoted to longer-term measures, if necessary.

- In reaction to the attacks, the insurance industry raised its premiums, reduced coverage and called on governments to step in and cover risks deemed too large for the private sector. Indeed, risks related to terrorism are difficult to price, not least because of the possibility that several catastrophic events occur at once (correlated risk). However, private sector initiatives specifically tailored to provide insurance for this type of risk are emerging. Market-based instruments, such as catastrophe bonds, are also available, although they are at present not actively traded. Private sector coverage of terrorism risk may therefore be restored in the future. Government intervention to fill the gap in the meantime should be considered with caution and limited in time and scope. Mega-terrorism, however, poses special challenges which cannot be fully addressed by the private sector and may require international options.

- The disruptions in the transportation system following the attacks have illustrated the importance of efficient and open borders for the daily operations of firms. The just-in-time supply chain management system, increasingly common in industry, depends to a large degree on the efficiency of border crossings. The severe tightening of border controls following the September attacks resulted in long waiting times that disrupted the operations of manufacturing companies, especially at the US-Canada border. Border controls have now been relaxed and waiting times reduced, but some observers feel that the porosity of borders creates a security threat. Attempts to reinstate comprehensive controls at the borders would have long-lasting detrimental consequences for economic growth. Industrial sources estimate that proposed security measures may increase the ad valorem cost of trading internationally by 1 to 3 percentage points. Given that the elasticity of trade flows with respect to transaction costs may be in the -2 to -3 per cent range, this could lead to a significant drop in international trade, negatively affecting openness, productivity and medium-term output growth. Thus, the right balance between efficiency and security at the border needs to be found, preferably in agreement with trading partners and on a non-discriminatory basis. 
- To combat terrorism, public spending on homeland security and military operations has been raised significantly in the United States and to a lesser extent in other OECD countries. Private sector spending is likely to be on the rise as well to improve the security of premises, employees and information. This may crowd out the accumulation of directly productive capacity, increase the cost of capital, raise wages and divert R\&D activities toward military projects. Therefore, the benefits associated with the peace dividend may be reduced. Rough calibrations suggest that an increase in public military-security spending by 1 per cent of GDP and private security spending by 0.5 per cent of GDP would reduce output by about 0.7 per cent after five years. Hence, the step-increase in anti-terrorism spending ought to be accompanied by a hard look at the costs and benefits of other military programmes, along the lines of what is intended more generally in the budget for non-defence spending. In addition, tighter security may reduce the level of productivity as, for instance, waiting times lengthen at airports and borders. Public financial support to strategic industries (such as aviation) and protectionist measures could also distort competition and reduce productivity growth. Although these effects should remain small based on measures currently announced, caution needs to be exercised.

\section{Short-run impact and crisis management}

4. The 11 September attacks inflicted casualties and material damages on a far greater scale than any terrorist aggression in recent history. The destruction of physical assets was estimated in the national accounts to amount to $\$ 14$ billion for private businesses, $\$ 1.5$ billion for State and local government enterprises and $\$ 0.7$ billion for Federal government. ${ }^{4}$ Rescue, cleanup and related costs have been estimated to amount to at least $\$ 11$ billion. Lower Manhattan lost approximately 30 per cent of its office space and scores of businesses disappeared. Close to 200000 jobs were destroyed or relocated out of New York City, at least temporarily. ${ }^{5}$ Within weeks of the attacks, bio-terrorism came to the fore. Lethal anthrax spores were found to have contaminated mail, causing several deaths. At the same time, awareness of a number of other sources of threats increased. Concerns were raised about the vulnerability of critical infrastructure, including computer systems (see Annex 1), power plants, nuclear facilities, chemical factories, dams, bridges, pipelines and water supply. The threat of mega-terrorism ceased to be considered as pure fiction (Box 1).

4. These property losses are reflected in the US national accounts as an increase in the consumption of fixed capital and therefore a reduction in net domestic product, but not in GDP, which measures the production of goods and services.

5. See DRI-WEFA (2002). 
ECO/WKP(2002)20

\section{Box 1. The risk of mega-terrorism}

Over the past few decades, dozens of aggressive movements have emerged espousing varieties of nationalism, religious fundamentalism, fascism and apocalyptic millenarianism. ${ }^{1}$ Terrorist threats and actions have come in many guises, including aircraft hijackings in the 1970s, the 1983 suicide attack on US and French contingents of the multinational peacekeeping force in Beirut, the 1993 attack on the World Trade Center, the 1993 bombing in the City of London, the 1995 sarin gas attack in the Tokyo metro and the 1996 bombing of a US military compound in Saudi Arabia, which put terrorism at the forefront of the subsequent G7 summit. Recent terrorist attacks (Oklahoma City, Khobar Towers, US Embassies in Kenya and Tanzania) have been increasingly more destructive and claimed a growing number of victims (see Lake, 2000).

The 11 September attacks exceeded in scale and audacity those of previous events. Yet, attacks on an even broader scale may occur. ${ }^{2}$ The US government, intelligence and military leadership have repeatedly warned that new attacks may happen in the near future. Attacks using weapons of mass destruction, although considered to have a remote probability, are not ruled out by security experts. The US government is taking the risk seriously and has reportedly activated, immediately after the 11 September attacks, a contingency plan (Continuity of Operations Plan) hat involves housing senior officials in nuclear shelters. ${ }^{3}$ The US VicePresident is also subject to special security procedures.

According to security specialists, terrorists could at some stage attempt to explode a nuclear device or release contagious viruses in a populous metropolitan area (see Stern, 1999). During the Cold War, the Soviet Union developed "suitcase" nuclear bombs that could be carried by a single person. Although the Russian authorities have taken steps to protect nuclear material from theft, it is not clear that all devices can be accounted for (see Allison, 2001). Even a crude nuclear device could create an explosive force of 20000 tons of TNT, demolishing an area of about three square miles. If detonated in lower Manhattan, the whole Wall Street and financial district would be destroyed and hundreds of thousands of lives would be lost.

Assessing the economic impact of such a terrorist attack is nearly impossible. Nonetheless, orders of magnitude may be helpful to evaluate what governments would have to deal with. An attack against, for instance, New York City using a nuclear weapon could leave most of the metropolitan area uninhabitable for years. The direct impact would reduce the country's production potential by about 3 per cent, ${ }^{4}$ that is, the equivalent of a small OECD country's GDP. The brunt of the direct impact would be borne by the financial industry, which represents the bulk of the city's economy. Wall Street would be closed for a protracted period of time and the recovery of financial transactions would depend on the availability of back-up facilities and data duplication. Hence, supervisory measures to ensure the continuity of businesses after a destructive attack may be desirable (see Ferguson, 2002). Another local impact with broad implications would be the severe disruption to the transportation system. New York's port and airports would be closed for a long time, and other transportation facilities would be subject to severe security measures, meaning a much slower and less predictable delivery system.

Nationwide, both household and business confidence would be badly shaken, as well as the trust in the Government's capacity to protect the country. The displacement of the surviving population to non-contaminated areas would create the need for new housing. As standard insurance policies exclude nuclear attacks, the cost of reconstruction would fall on the budget, and the fiscal outlook would deteriorate markedly. The recent shrinkage of coverage for terrorism-related risks (see below) would also leave most businesses dangerously exposed. Over the long term, such an attack would sharply reduce the readiness of persons and businesses to agglomerate in metropolitan areas. The trend would therefore be to disseminate in less populated areas, which may have a negative impact on innovation and productivity growth. Overall, a second terrorist attack could have longer-lasting effects, especially one using weapons of mass destruction. In view of this, preparedness should be seen as essential, even if the possibility of such an attack is considered as remote.

1. For overviews, see for instance Laqueur (1996) and Reich (1998).

2. This risk is taken seriously by the insurance sector as well. For example, in a letter to shareholders, the Chairman of a major US insurance group contemplated the possibility of a disaster wrecking $\$ 1$ trillion in damage (Buffett, 2002).

3. Washington Post, 3 March 2002.

4. The gross state product of the State of New York was $\$ 755$ billion in 1999, about 8 per cent of the country's GDP. Using labour force statistics, the city of New York appears to account for about 40 per cent of the state. Hence, a rough estimate is that New York City represents about 3 per cent of the country's total output.

5. Glaeser and Shapiro (2001). 


\section{The adverse conjunctural impact was sharp but temporary...}

5. By early September 2001, household and business confidence in the United States as well as in most other OECD countries had already weakened considerably compared with their 2000 peaks (Figure 1). ${ }^{6}$ The attacks further dented confidence. In the United States, consumer and business surveys showed falls in the overall confidence measures akin to those observed in the wake of the Iraqi invasion of Kuwait in 1990, and much larger than those following terrorist attacks in the 1990s. In Europe and Japan, confidence was also weakened, albeit less sharply. Forecasters responded with one of the largest one-time collective downward revisions in recent history. Thus, the consensus forecast for US real GDP growth was instantly downgraded by 0.5 percentage point for 2001 and 1.2 percentage points for 2002 (Figure 2). The implied projected cumulative loss in national income through the end of 2003 amounted to 5 percentage points of annual GDP, or half a trillion dollars.

Figure 1. Confidence

\section{A. United States over the long run}

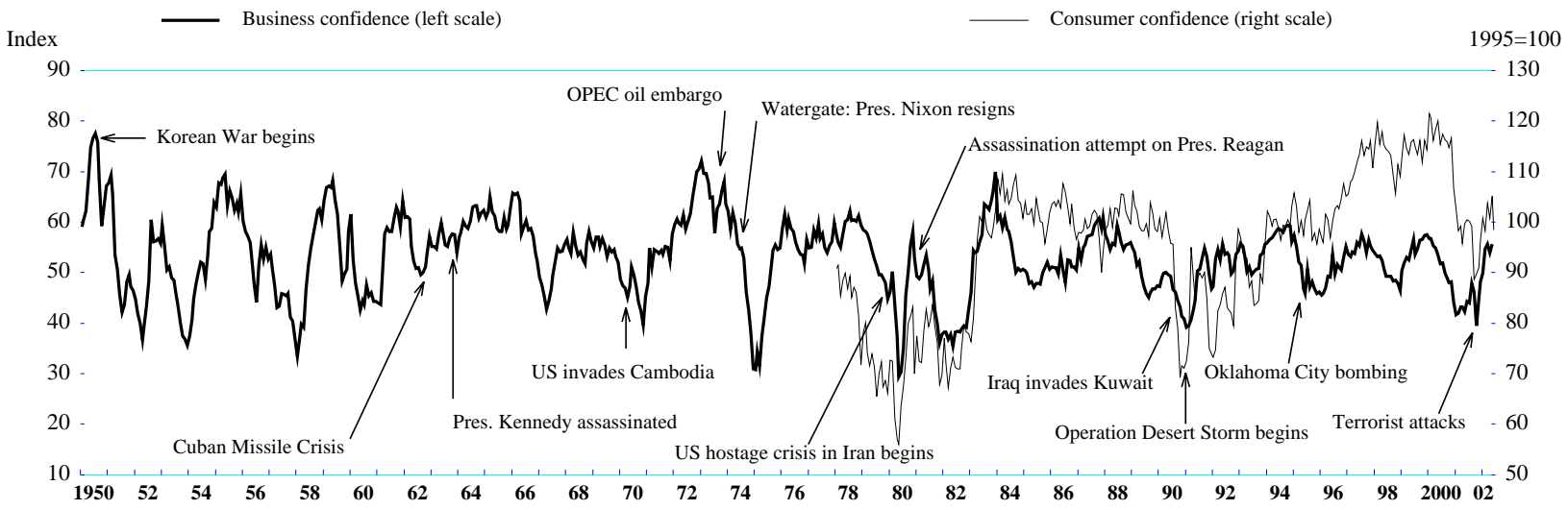

B. Since January 2000
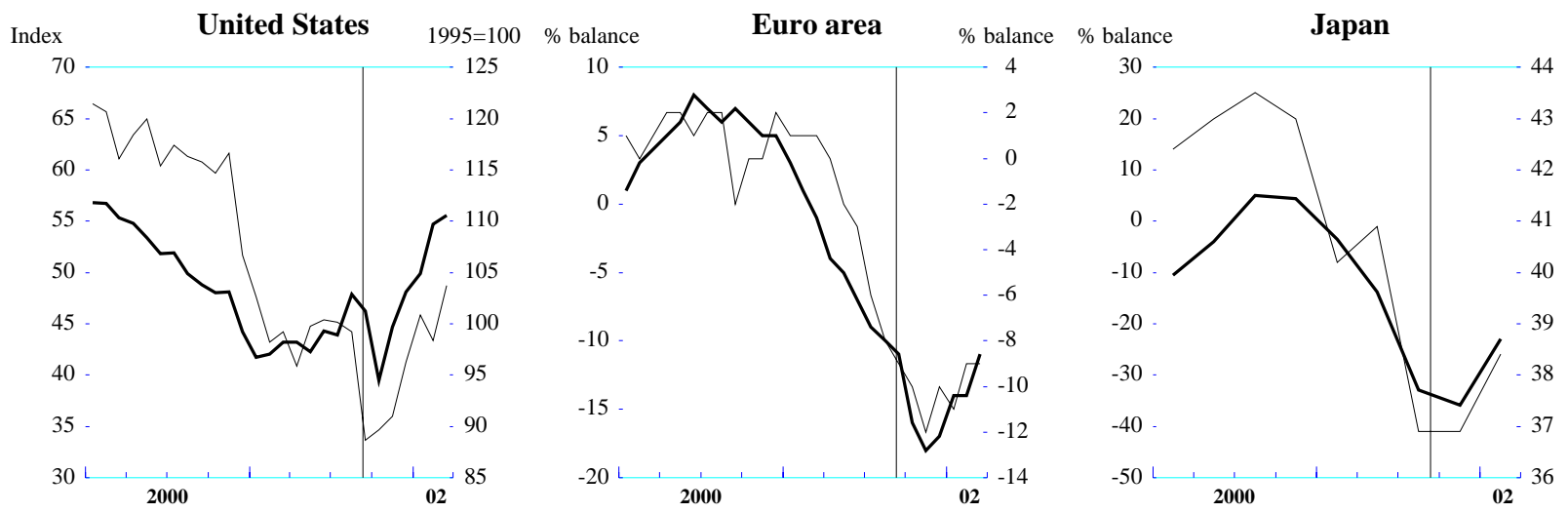

Source: OECD Main Economic Indicators.

6. In the United States, the National Bureau of Economic Research subsequently declared that the cycle had peaked in March 2001. The euro area was within measurement error distance of a technical recession starting in the second quarter of 2001. Real GDP declined in Japan in the second and third quarter of 2001. 
Figure 2. A step-adjustment in forecasts

US real GDP level, 2000Q4=100, saar

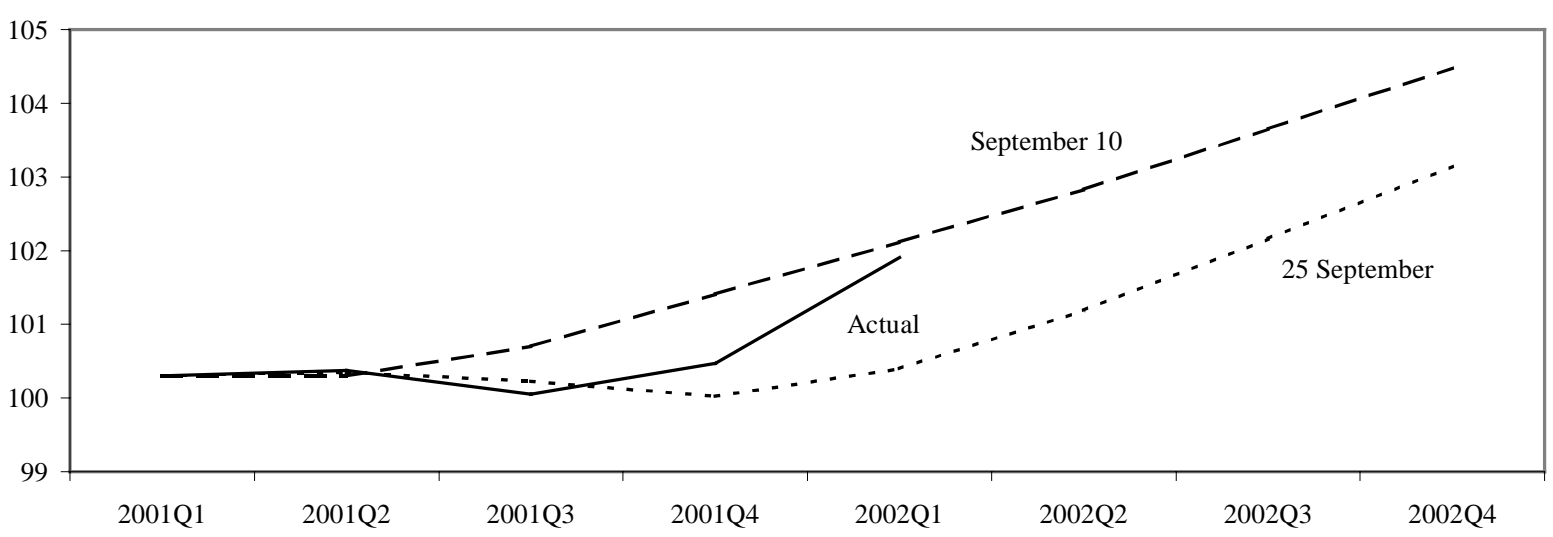

Source: Consensus Economics (regular monthly survey and special post-11 September survey), US Bureau of Economic Analysis.

6. Near-term prospects not only became gloomier overall, but uncertainty greatly increased. Whereas private sector forecasts for US growth in 2002 symmetrically and narrowly clustered around $2 \frac{1}{2}$ per cent on the eve of the attacks, they very unevenly shifted down during the following weeks (Figure 3). ${ }^{7}$ In fact, the distribution of forecasts became multimodal, altering the very meaning of any single summary measure of what would be a consensus forecast.

Figure 3. Uncertainty increased

Distribution of private sector forecasts for 2002 US real GDP growth
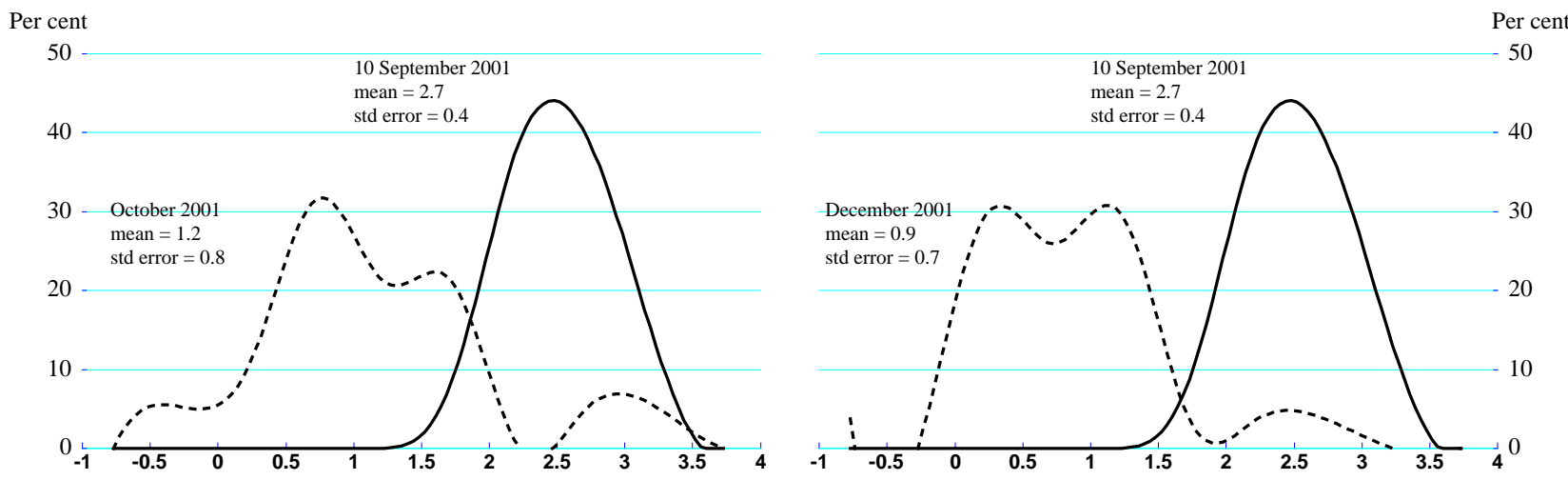

Sources: Consensus Economics, OECD.

7. The 25 September Consensus Economics survey results were not broken down across forecasters. Therefore, the October data are used in Figure 2. 
Figure 4. Stock prices

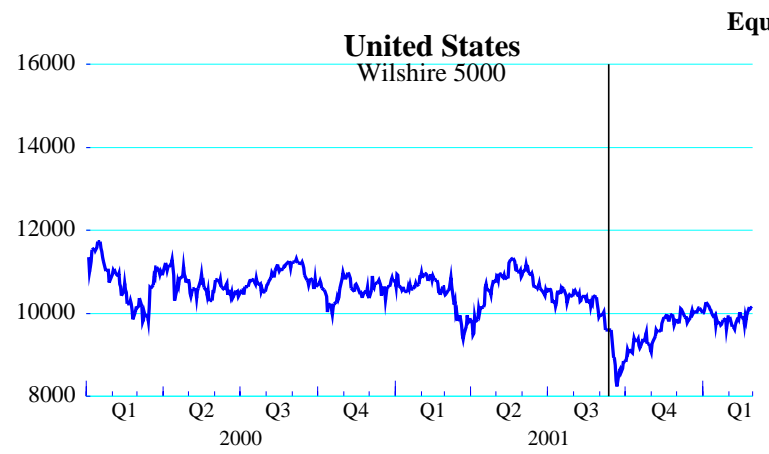

Equity market indices
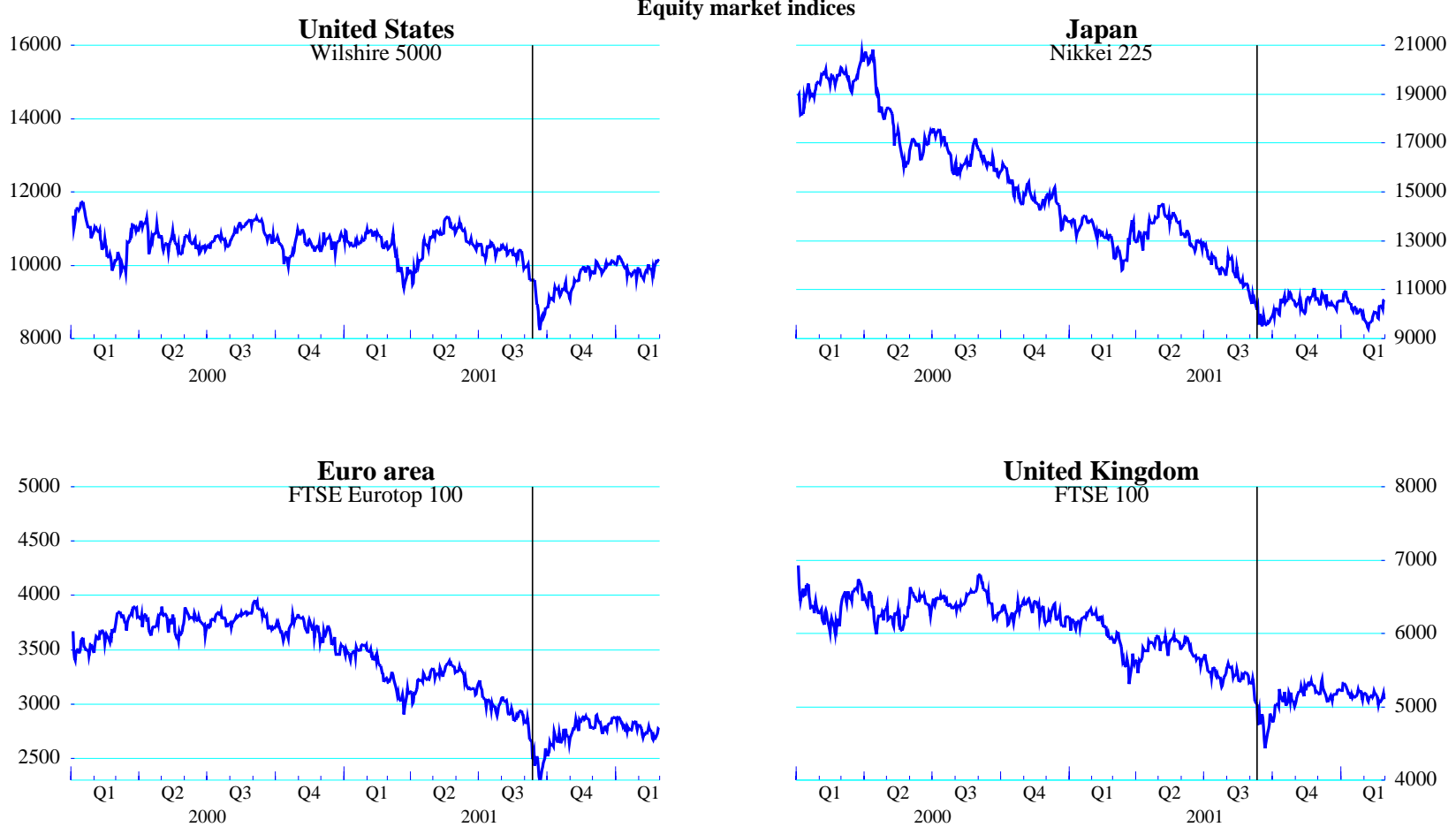

Implicit volatility
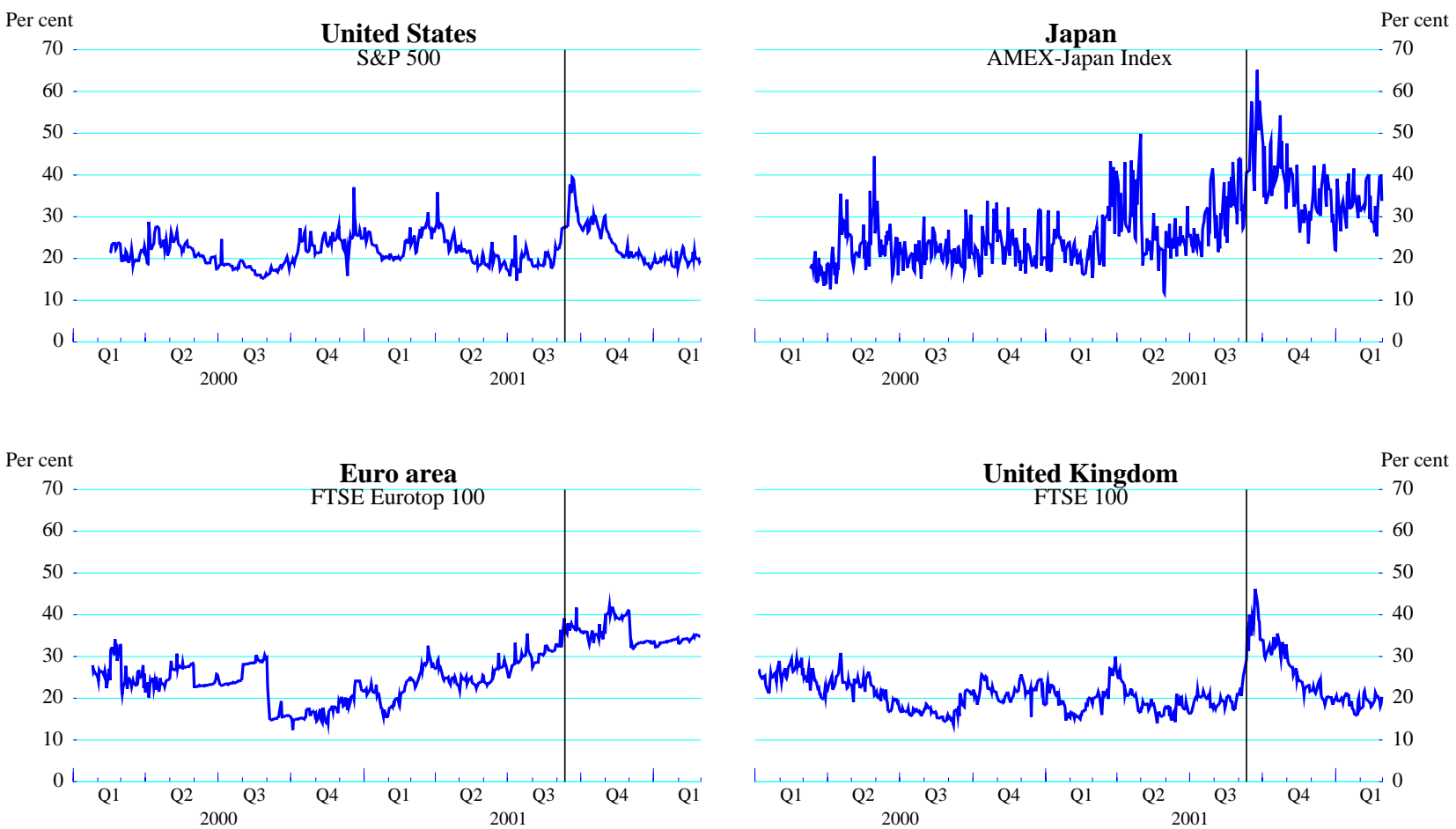

Source: Datastream. 
Figure 5. Credit spread between corporate and government benchmark bonds ${ }^{1}$
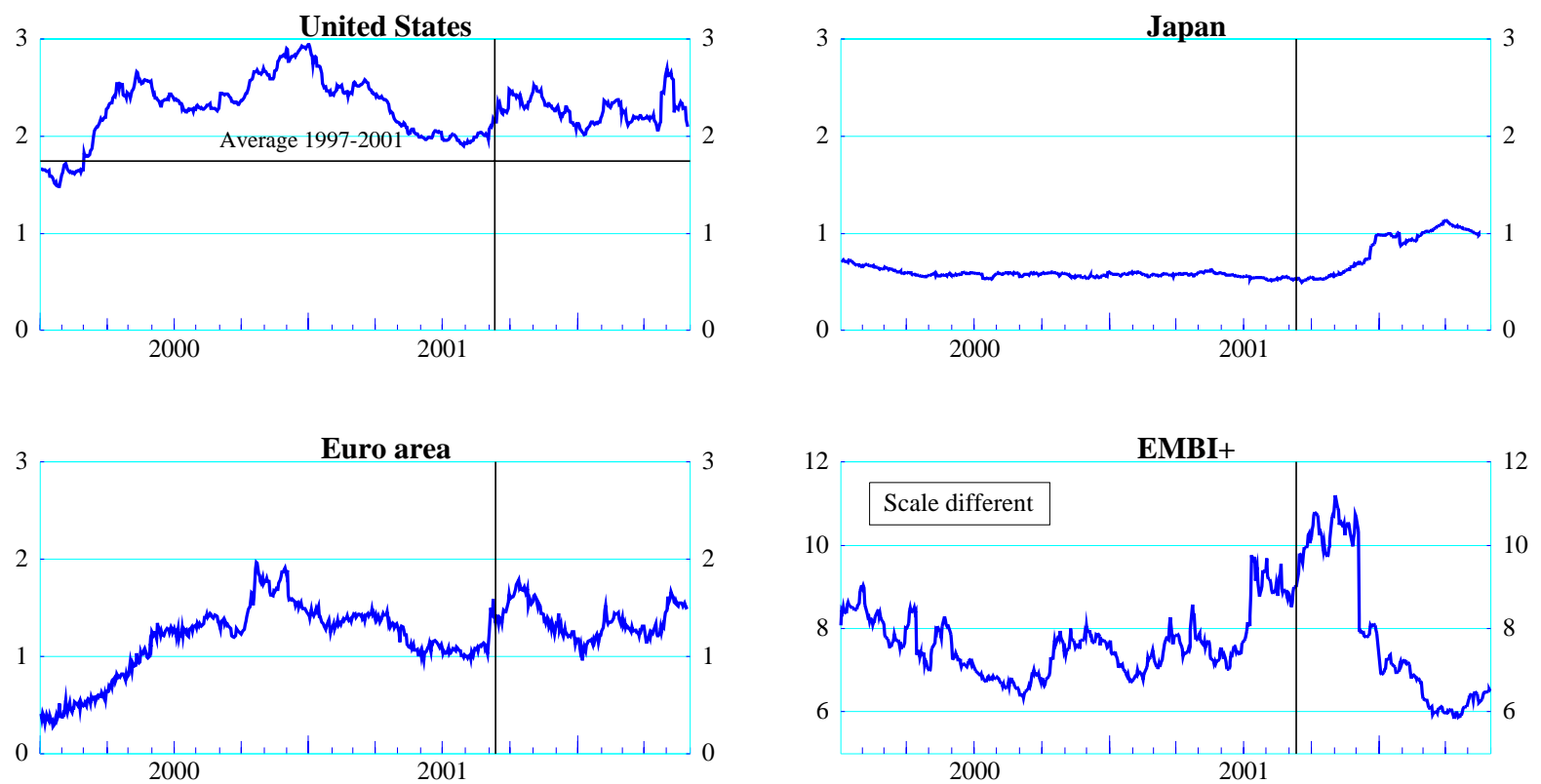

1. United States: Lehman Baa corporate index; Japan: Baa bonds; Euro area: Lehman euro Baa; EMBI+ :JP Morgan Emerging Market Bond Index. Government bond yields are for 10-year benchmark bonds, except Japan, 5-year. For the EMBI+ spread refers to the gap between the interest rate a sovereign party pays on its dollar denominated debt and American Treasury bonds.

Source: Datastream, Japanese Securities Dealers Association, Federal Reserve Board, JP Morgan.

7. Uncertainty likewise increased in financial markets, with risk premia shooting up and a "flight to quality". Equity prices tumbled (Figure 4). Spreads between corporate and government bond yields, as well as spreads between emerging market and US bond index yields widened (Figure 5). Implied volatility as derived from traded options on equity indices, government bond prices, short-term interest rates, exchange rates and commodities spiked upwards. These indicators pointed both to lessened risk appetite and to higher perceived risk. ${ }^{8}$ But by the end of 2001, and not unlike during earlier wartime episodes (Table 1), equity prices had bounced back vigorously, in many cases to well above their 10 September levels. As well, spreads had generally narrowed and implied volatility had declined significantly. Furthermore, a survey of major transnational corporations conducted in November 2001 showed that only a few of them intended to delay or cancel investment projects for the next three to five years as a result of the terrorist attacks. ${ }^{9}$ On the whole, the shock to financial markets thus seems to have been largely transitory.

8. Separating the two is difficult. Kumar and Persaud (2001) have attempted to do so.

9. See UNCTAD (2001). 
Table 1. Stock price recoveries

\begin{tabular}{|c|c|c|c|}
\hline \multicolumn{4}{|c|}{$S \& P 500$, per cent changes } \\
\hline & Reaction period & Reaction & One year later ${ }^{a}$ \\
\hline Pearl Harbor & 7 to 29 Dec. 1941 & -10.2 & 15.3 \\
\hline Korean War & 23 June to 17 July 1950 & -12.9 & 31.4 \\
\hline Cuban missile crisis & 23 Aug. to 26 Oct. 1961 & -8.8 & 36.6 \\
\hline Tet offensive, Vietnam War & 31 Jan. to 5 Mar. 1968 & -5.6 & 13.7 \\
\hline Iraqi invasion of Kuwait & 2 Aug. 1990 to 16 Jan. 1991 & -11.1 & 32.3 \\
\hline 11 September, 2001 & 11 to 19 Sep. $2001^{b}$ & -7.0 & 15.0 \\
\hline
\end{tabular}

8. With production severely disrupted and consumers temporarily limiting shop visits, real GDP shrank in the third quarter. But in the fourth quarter, demand held up better than initially feared, and GDP increased. Labour shedding accelerated, with the attacks serving as a proximate or genuine motivation, and unemployment rose sharply, from 5.0 per cent of the labour force on the eve of the attacks to 5.8 per cent by December (seasonally adjusted). Private sector fixed investment registered a steep decline, and inventories were slashed. Offsetting these forces, however, were household consumption, helped by falling energy prices and aggressive discounting in the automobile sector, and government spending. Defence spending, in particular, grew by about $9 \frac{1}{2} 2$ per cent in real terms in the fourth quarter, at a seasonally adjusted annual rate.

9. While overall demand proved fairly resilient, a number of sectors were hit hard. Airlines, many of which were already in mediocre financial shape prior to the attacks, suffered a substantial loss in capital and in demand, both in the United States and in many other OECD countries. Aircraft manufacturers almost immediately saw orders curtailed. The insurance sector faced a catastrophe of unprecedented severity. Hotels, restaurants, travel agencies and other tourism-related businesses confronted a sharp drop in demand, in the United States but also in many other countries, in particular in the Caribbean and in the Middle East. In the retail sector, customers initially tended to desert upscale department stores in favour of large discount outlets. The US Postal Service recorded an abrupt decline in mail traffic (Figure 6). Some sectors or firms, however, witnessed an increase in demand, notably in the area of security and information technology (e.g. producers of biometric and other screening devices).

Figure 6. Mail

Total volume, per cent change over a year earlier

Per cent

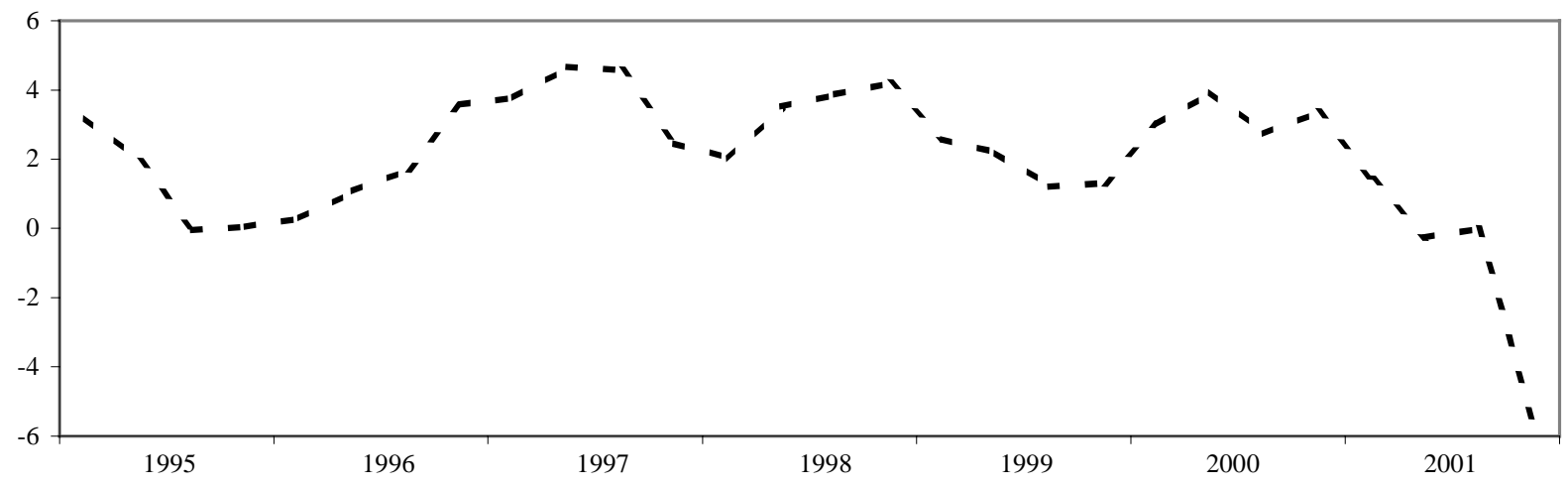

Source: US Postal Service. 


\section{Large temporary liquidity injections by the Federal Reserve safeguarded the financial system}

10. The attacks destroyed or disabled whole portions of New York's financial infrastructure, with potentially devastating domestic and international reverberations. Financial markets were shut down, and remained closed until Monday 17 September. The Federal Reserve instantly indicated that it stood ready to inject virtually unlimited amounts of liquidity to avoid payment failures and cascading defaults. The Fed's New York trading desk, operating from its primary emergency backup site, engaged in massive repo operations: it's holdings of securities under repurchase agreements more than doubled from an average of $\$ 24$ billion in the preceding six weeks to $\$ 61$ billion on 12 September (Figure 7). ${ }^{10}$ The Fed also lent money directly to banks through the discount window, lifting the stigma normally associated with this facility, and outstanding loans surged from an average of $\$ 21$ million in the preceding six weeks to $\$ 46$ billion on 12 September. Furthermore, the Fed gave credit for deposited checks being cleared through its books before the amounts were deducted from other banks' accounts, extending \$23 billion in check float on 12 September, close to two hundred times the average over the preceding six weeks. It also kept the Fedwire open late into the night to facilitate payment execution. Against this background, the effective Fed funds rate plunged to levels last seen in the early 1960s, troughing at 1.2 per cent on 19 September. On the international front, the Fed established or expanded 30-day swap lines with the European Central Bank, the Bank of England and the Bank of Canada, totalling a record $\$ 90$ billion, so as to enable them to provide dollars to their financial institutions. These and other major central banks also provided their market participants with extra liquidity. ${ }^{11}$

11. At the same time, along with the Comptroller of the Currency, the Fed urged banks to roll over loans for borrowers facing temporary liquidity problems, indicating it was ready to assist with additional funds. In addition, the Fed temporarily waived the usual fees and penalties on daylight and overnight overdrafts so as to ease banks' problems in managing their reserve positions. Likewise, the rules on securities lending were suspended for a while to make additional collateral available to the markets. Banks were also notified that regulatory capital requirements would be administered flexibly. Meanwhile, the Securities and Exchange Commission exercised one of the emergency powers it was granted in the wake of the 1987 stock market crash by temporarily lifting the limits on the repurchase by firms of their own stock. In many other countries, the supervisory authorities took similar regulatory forbearance measures.

12. In the days following the attacks, all interested parties worked inexhaustibly to rebuild communication and power connections and to ensure the smooth and timely reopening of markets. As the financial markets and payment infrastructure returned to normal, loans were repaid, and the temporarily bloated balance sheet of the Fed shrank rapidly. By 19 September, repo holdings were down to $\$ 40$ billion and discount loans outstanding to $\$ 2.6$ billion. Over the next two days, the effective Fed funds rate moved back up to around 3 per cent. As in previous episodes of financial stress -- such as the 1987 stock market crash, the 1998 Russian default and LTCM debacle, and the Y2K scare -- the Fed managed to preserve the integrity of the financial system. That said, the fact that banks and securities firms generally entered this crisis with strong capital bases and sound liquidity positions also helped to avoid a systemic breakdown.

10. Data are normally available only for Wednesdays and week averages. Figure 7 shows weekly averages.

11. For further details, see Cumming (2002). 
Figure 7. Liquidity injections and Federal funds rates

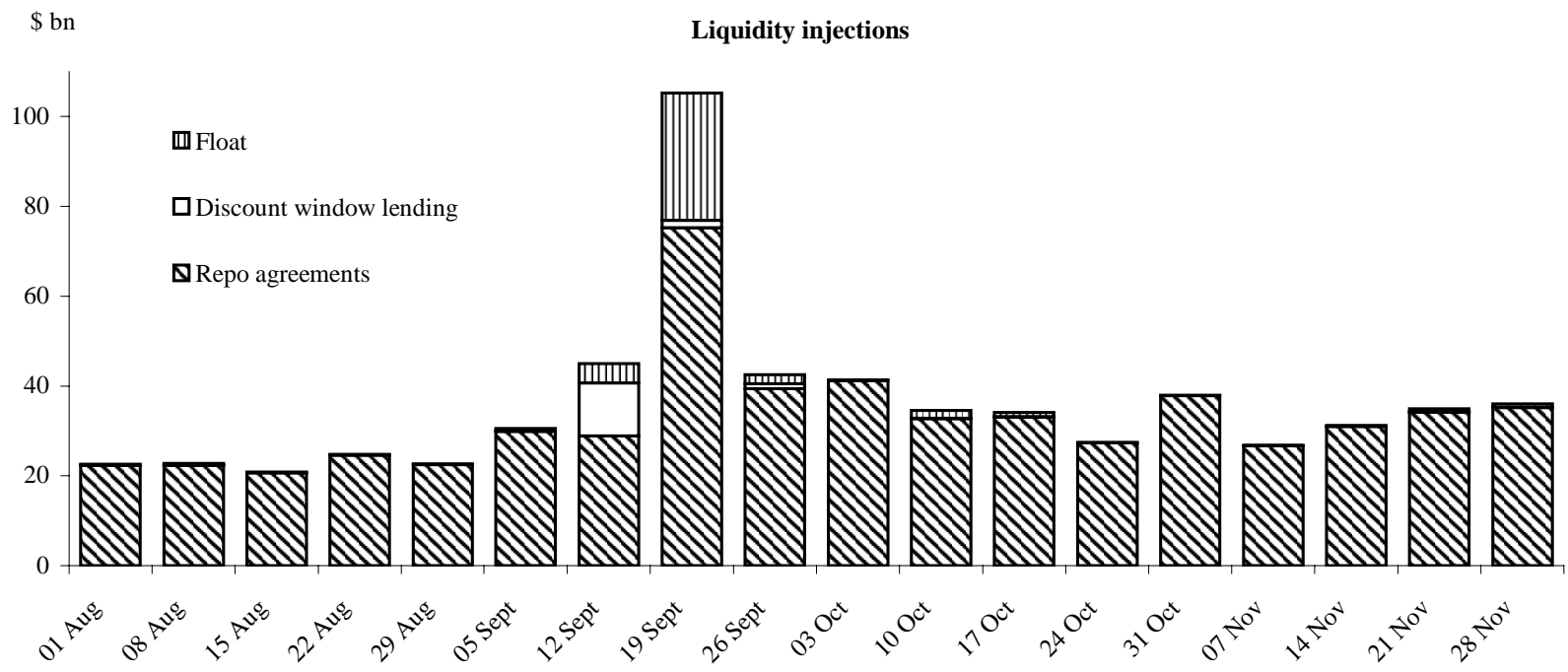

\begin{tabular}{ll} 
Per cent $\quad$ Federal funds rates \\
\hline
\end{tabular}

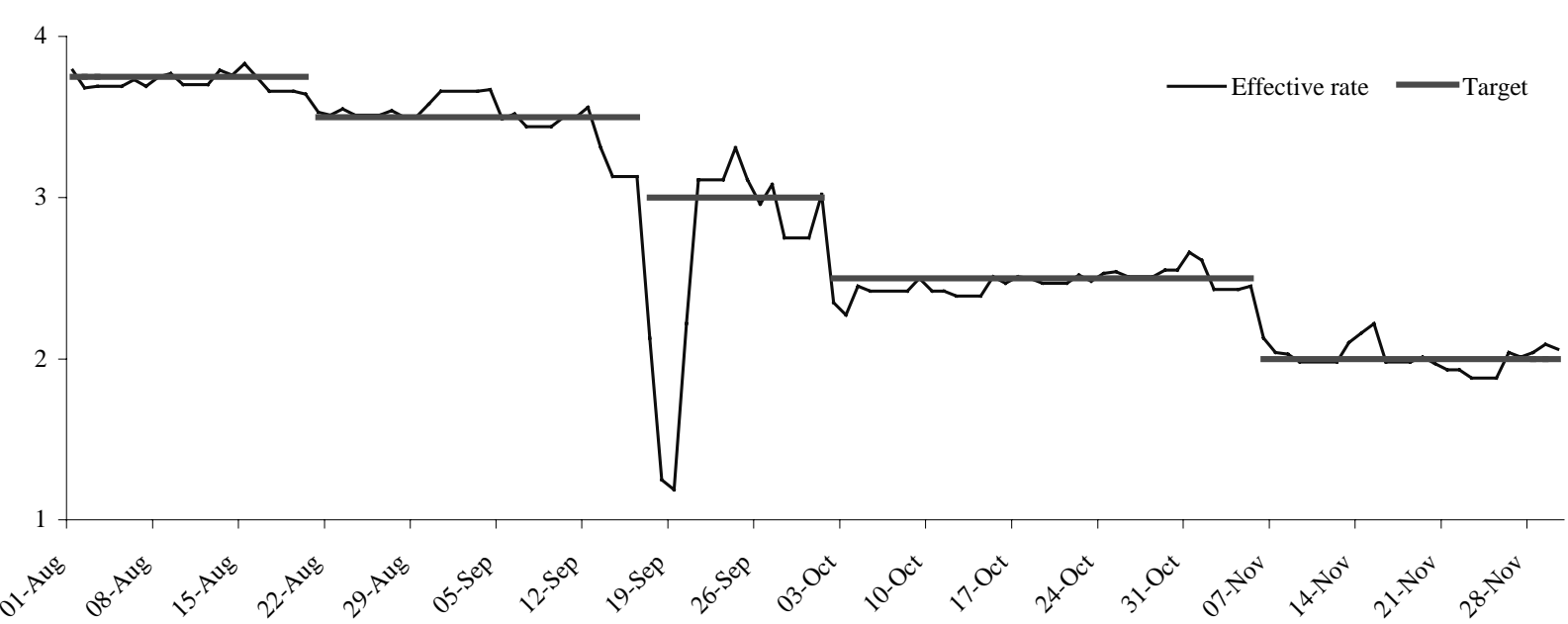

Source: Federal Reserve Board.

\section{The macroeconomic policy response was vigorous and swift}

13. On Monday 17 September, and before the reopening of the stock markets, the Fed cut its target rate by 50 basis points at an unscheduled meeting. During subsequent weeks, the target rate was brought down in steps by another 125 basis points. While the counterfactual is bound to remain hypothetical, it can be noted that the consensus forecast on the eve of the attacks was for a cumulative cut by end-year of only 30 basis points. Two weeks later, the consensus forecast was for a 60 basis point cut on top of the 17 September one. On this evidence, the shock and its immediate repercussions led the Fed to move much further than would otherwise have been the case. The same holds for many other central banks in OECD countries as well as elsewhere. Thus, in the weeks following the attacks, both the Eurosystem and the Bank of England trimmed their policy rate by 100 basis points, while the Bank of Canada reduced its target rate by 175 basis points. 
14. The fiscal stance had started to be relaxed well before the attacks. In the United States, Congress had passed a major package of tax cuts in June 2001, which was estimated to reduce revenues by 0.7 percentage points of GDP in FY 2001. Tax refund checks had started to be sent out in late July. In Europe, many countries had embarked around the late 1990s on medium-term tax reduction programmes. Ex post, the implied loosening of the fiscal stance turned out to be well timed, at least in the countries where fiscal consolidation had progressed sufficiently.

15. On 14 September, the US Congress cleared a $\$ 40$ billion supplemental appropriation emergency spending package. At least half of the money was to be used for relief related to the destruction in Manhattan, at the Pentagon and in Pennsylvania. Ten billion dollars were available immediately for emergency rescue and rebuilding efforts, tightening security at airports and other transportation centres and at public buildings, investigating and prosecuting those involved in planning and executing the attacks, and enhancements to national security. A few days later, Congress authorised $\$ 5$ billion in direct grants plus $\$ 10$ billion in federal loan guarantees for the US airlines. The actual outlays, however, were to fall mostly in the fiscal year starting on 1 October and beyond. They contributed to the aforementioned acceleration of public spending in the fourth quarter of 2001. Limited discretionary fiscal stimulus action was taken in other OECD countries, not least because many of them had less room for manoeuvre. State aid was granted to airlines in the European Union (EU) as compensation for the losses resulting directly from the four-day closure of US airspace, but on a smaller scale. ${ }^{12}$

16. Following the approval of the emergency package, a variety of proposals were tabled for a set of fiscal stimulus measures, including an extension of unemployment insurance benefits, personal and corporate income tax cuts, and other tax relief provisions -- involving an injection of up to 1 per cent of GDP. Agreement on the shape of an additional package was not found before March 2002, however, when a compromise was reached on a package worth 0.5 per cent of GDP and consisting mainly of unemployment benefit extension and business tax relief measures. With the benefit of hindsight, the gridlock may actually have been a blessing in disguise, avoiding too large a fiscal push, which might have turned out to be pro-cyclical.

17. The US authorities also promptly took a number of regulatory measures. Border controls were tightened. An executive order was issued freezing the US assets of terrorists, terrorist organisations and their sponsors and associates, and banning financial dealings with them. At the international level, the mandate of the Financial Action Task Force (FATF) was broadened (Box 2). Security-related restrictions were imposed or reinforced in most OECD countries. Governments also stepped in to provide temporary backstop insurance for terrorism risk, although in the United States more ambitious initiatives to that effect were not immediately approved by Congress. ${ }^{13}$

12. For example, France granted $€ 55$ million, Germany $€ 71$ million and the United Kingdom $£ 40$ million. Rescue financing was arranged for Sabena and Swissair, which went bankrupt.

13. The House of Representatives approved a terrorism-insurance bill in November 2001. A different version of the bill was approved by the Senate in June 2002. At the time of writing, the two versions still needed to be reconciled before they could be signed into law by the President. 


\section{Box 2. The Financial Action Task Force}

On 31 October 2001, the FATF agreed to eight Special Recommendations against terrorist financing which commit members to: take immediate steps to ratify and implement the relevant United Nations instruments; criminalise the financing of terrorism, terrorist acts and terrorist organisations; freeze and confiscate terrorist assets; report suspicious transactions linked to terrorism; provide the widest possible range of assistance to other countries' law enforcement and regulatory authorities for terrorist financing investigations; impose anti-money laundering requirements on alternative remittance systems; strengthen customer identification measures in international and domestic wire transfers; and ensure that entities, in particular non-profit organisations, cannot be misused to finance terrorism.

The FATF subsequently developed a self-assessment questionnaire to help evaluate the level of implementation of the Special Recommendations. In January 2002, FATF member jurisdictions completed the first phase of a self-assessment exercise against the Special Recommendations. All other countries have also been invited to participate on the same terms as FATF members. In April 2002, the FATF issued a document describing the methods of terrorist financing and the types of financial activities constituting potential indicators of such activity. The aim of this guidance is to assist financial institutions and other vulnerable entities in detecting and reporting terrorist financing through the existing anti-money laundering channels. ${ }^{1}$ In addition, the FATF has begun developing a process to identify weaknesses in the world-wide efforts to combat terrorist financing. This process will include the development of guidance on implementing the Special Recommendations and the identification of jurisdictions with inadequate measures to combat the financing of terrorists.

1. The 2002 FATF typologies report includes an in-depth analysis of the methods used in the financing of terrorism. This report and the guidance will be updated regularly as the FATF and its members increase their knowledge of the financing of terrorism. The report is available through the FATF website at: http://www.fatf-gafi.org.

18. Overall, the short-term adverse economic impact of the attacks was far less than feared initially, thanks in large part to good economic crisis management. The Federal Reserve, the US Administration and Congress acted quickly to restore confidence, inject liquidity and provide resources to deal with the consequences of the attacks. Lowering the price of credit and temporarily providing vast amounts of liquidity helped safeguard the integrity of the financial system and save firms from bankruptcy, and was perhaps more important than bailing out firms with budgetary resources. International co-operation, not least at the level of the monetary authorities, also helped.

\section{Medium-term economic consequences}

19. Even though the strong policy response mitigated the short-term direct impact, medium-term implications from the attacks should not be under-estimated. In general, little research is available regarding the long-lasting impact of terrorism. A case study on the terrorism-prone Spanish Basque region ${ }^{14}$ suggests a permanent drop in output, but this is largely related to the displacement of economic activities to more secure regions and does not apply to a large national economy. Half a year after the events, nonetheless, it appears clearly that three important consequences will be long-lasting: insurance coverage for terrorism-related activities is more difficult to obtain and premiums have increased considerably; pressure is mounting to tighten security at the borders and better screen the vast flows of merchandise entering OECD countries; public spending on security and military operations is on the rise. These three channels are discussed below.

14. See Abadie and Gardeazabal (2001). 


\section{The shrinkage of affordable insurance coverage: should governments intervene?}

20. The losses from the terrorist attacks for the insurance industry (including reinsurance) are estimated at between $\$ 30$ billion and $\$ 58$ billion, with the main uncertainty deriving from payments on liability insurance (Table 2). ${ }^{15}$ The attacks represented the largest insurance event in history, dwarfing the $\$ 21$ billion of losses incurred when Hurricane Andrew hit Florida in 1992. ${ }^{16}$ Even if the final cost is close to the lower estimate, insured losses in 2001 are likely to have been the highest ever (Figure 8).

Table 2. Insurance market losses

\begin{tabular}{lc}
\hline Line of business & Range (\$ billion) \\
\hline & \\
Property & $10.0-12.0$ \\
Business interruption & $3.5-7.0$ \\
Workers' compensation & $3.0-5.0$ \\
Aviation & $3.0-6.0$ \\
Liability & $5.0-20.0$ \\
Other lines (non-life) & $1.0-2.0$ \\
Life and health & $4.5-6.0$ \\
Total & $30.0-58.0$ \\
\hline
\end{tabular}

a) Preliminary (as of 31 January 2002).

Source: Tillinghast-Towers Perrin.

Figure 8. Insured losses 2001 prices

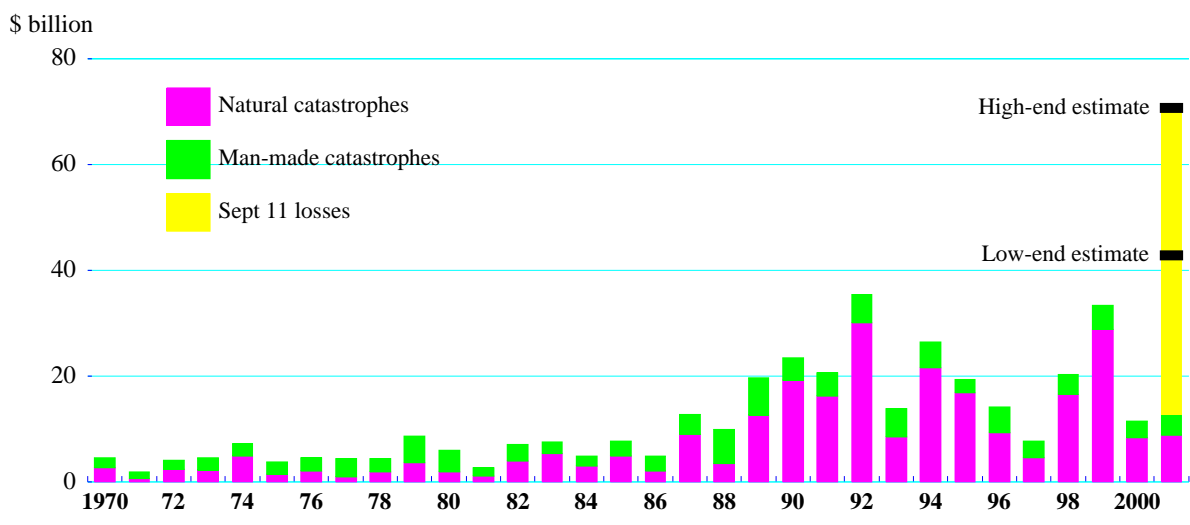

Source: Swiss Re, Economic Research \& Consulting and OECD.

15. As of the end of January 2002, claims for $\$ 27.4$ billion had been filed, mostly for commercial insurance.

16. Claims from the 1993 bombing of the World Trade Center amounted to $\$ 0.5$ billion. The 1992 Los Angeles riots were the most expensive man-made disaster to date, with claims of $\$ 0.8$ billion. These costs were almost entirely concentrated in property insurance claims. In contrast, the 11 September attacks have led to claims on a variety of types of policies: life, property, auto, airplane, workers compensation and business interruption insurance. 
21. In spite of the magnitude of these payments, no major bankruptcies have occurred in the industry, in part because the risk was spread over a number of companies and countries. It is estimated that reinsurers, most of them European, will incur over half of the losses. The capital base of many insurance and reinsurance companies has been severely hit, the shock having come on top of a series of other recent disasters (including a number of major storms) and portfolio losses associated with stock market declines. As a result, it is likely that several companies would not be in a position to withstand another shock of a similar magnitude. ${ }^{17}$

22. Following the attacks, primary insurers and reinsurers have hiked their premiums and curtailed or dropped altogether coverage for terrorism-related risk. ${ }^{18}$ The hikes in insurance premiums have hit several industries. The strongest impact has been on aviation (Box 3), but other sectors, including transportation, construction, tourism and energy generation have also been affected. Overall, it is estimated that commercial property and liability insurance rates have been raised by 30 per cent on average, with "target" structures such as chemical and power plants and "iconic" office buildings seeing steeper increases. This should be seen in the context of a sharp decline of premium rates in the 1990s, which in the case of reinsurance, had only started to be reversed in 2000 (Figure 9). Even with the projected hikes, reinsurance rates should remain well below the peaks reached in 1993, especially given enhanced competition in the industry, which limits the scope for further rate increases.

\section{Figure 9. Reinsurance rates ${ }^{1}$}

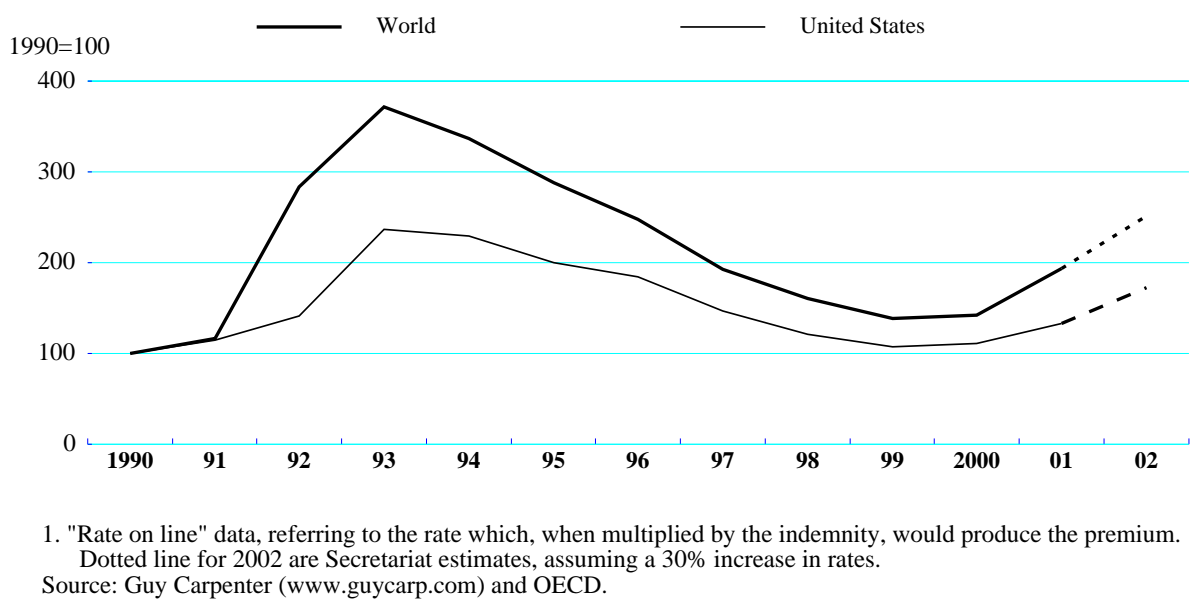

17. See Cummins et al., (2002).

18. General Accounting Office (2002). 


\section{Box 3. The impact on the airline industry}

The airline industry suffered major losses as a result of the terrorist attacks in the United States. Air traffic was completely shut down for four days in the United States and demand for air transportation services around the globe fell sharply in the following months. In the United States, revenue passenger miles (RPMs) fell by 32 per cent in September 2001, compared with a year earlier (Figure 10). In the same period, revenues from airfreight (including express) and airmail were down by 20 and 63 per cent respectively, as the latter was also affected by the anthrax scare (see above). The industry responded with a substantial curtailing of capacity, with available seat miles falling by about 15 per cent in the fourth quarter, compared with the same period of 2000. Reduced capacity and a gradual recovery in demand - RPMs in December and January were down by a less sharp 13 per cent from a year earlier - led to a strong recovery in passenger load factor (PLF). By January 2002, PLF was already above one-year earlier figures. The measures taken by the airline industry helped contain the fall in airfares, which declined by less than 4 per cent in the two months following the attacks. By comparison, airfares had declined by more than 6 per cent following Operation Desert Storm in 1991 (Figure 11).

US airlines were also hit by an increase in insurance costs, up 233 per cent in the fourth quarter (year on year). Insurance costs represented only 1 per cent of total operating expenses though, so higher rates were more than offset by a decline in fuel and interest payments. More seriously, reinsurers and insurers radically modified their policies for aviation cover, reducing coverage and sharply increasing premium rates. In the United States, insurers introduced exceptional premia of $\$ 1.25$ per transported passenger and raised premiums by 0.05 per cent per total insured fleet value. Insurers have also decided to limit the cover for third party damages caused by terrorist actions to $\$ 50$ million (instead of $\$ 1.5$ billion).

Given these challenges, the US government provided airline companies with direct financial help and reinforced airline security (see Annex 2). The Air Transportation Safety and System Stabilization Act of September 2001 provided $\$ 5$ billion in emergency assistance to compensate the nation's air carriers for losses resulting from the temporary shutdown of the nation's airspace and the severe drop in passenger traffic since the attacks. Passenger carriers were allocated $\$ 4.5$ billion, and cargo carriers $\$ 0.5$ billion. Besides these direct cash grants, airlines were provided with loan guarantees worth $\$ 10$ billion, but as of early 2002 , only one airline had taken up the offer. Finally, limits (of \$100 million per incident) were imposed on third-party liability damages.

In order to avoid disruption of the air traffic, many regulators (Australia, Denmark, Finland, France, Ireland, Germany, the Netherlands, the United Kingdom, Spain, Portugal, Sweden, Switzerland) also introduced measures to support third-party insurance for airlines companies. The EU Finance Ministers have approved a code of conduct, followed by most EU members, that sets the conditions under which EU governments may sustain aviation insurance. The code of conduct enabled those Member States so wishing, either to pay insurance premiums linked to the "risk of war and terrorism" for their airline companies, or to grant them a State guarantee against such risk.

1. To obtain government loan guarantees, airlines are required to provide equity options as collateral. 
Figure 10. Air traffic ${ }^{1}$

Domestic plus international

Cargo (total revenue ton-miles, in millions)

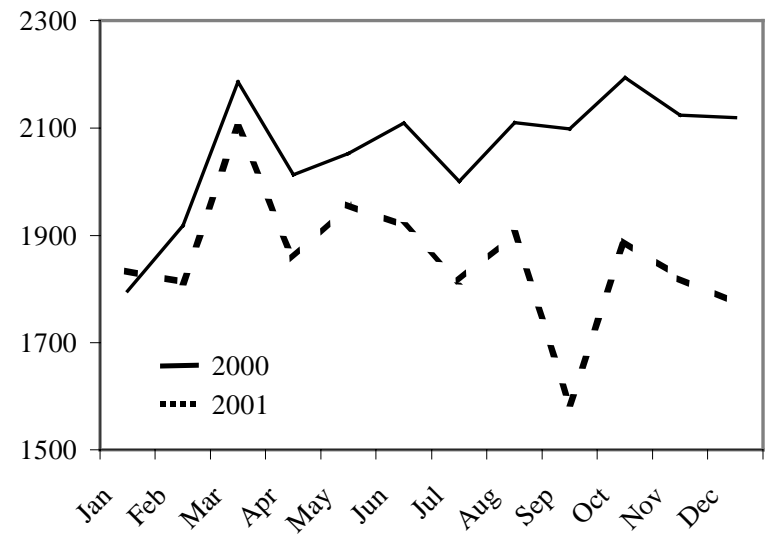

Revenue passenger miles (in billions)

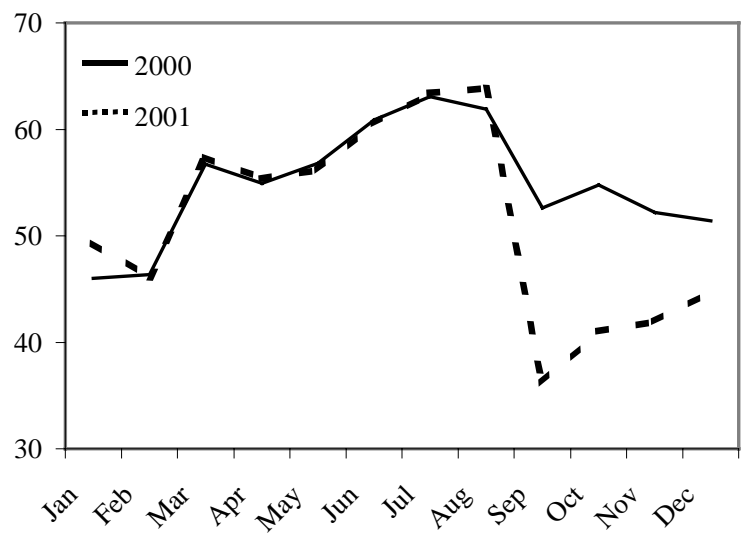

1. Includes the following carriers: Alaska, America West, American, Continental, Delta, Federal Express, Northwest, Southwest, Trans World, United, UPS, US Airways, Aloha, Continental Micronesia, Emery Worldwide, Hawaiian \& Midwest Express.

Source: Air Transport Association.

\section{Figure 11. Airfare price movements ${ }^{1}$}

Index event

month $=100$

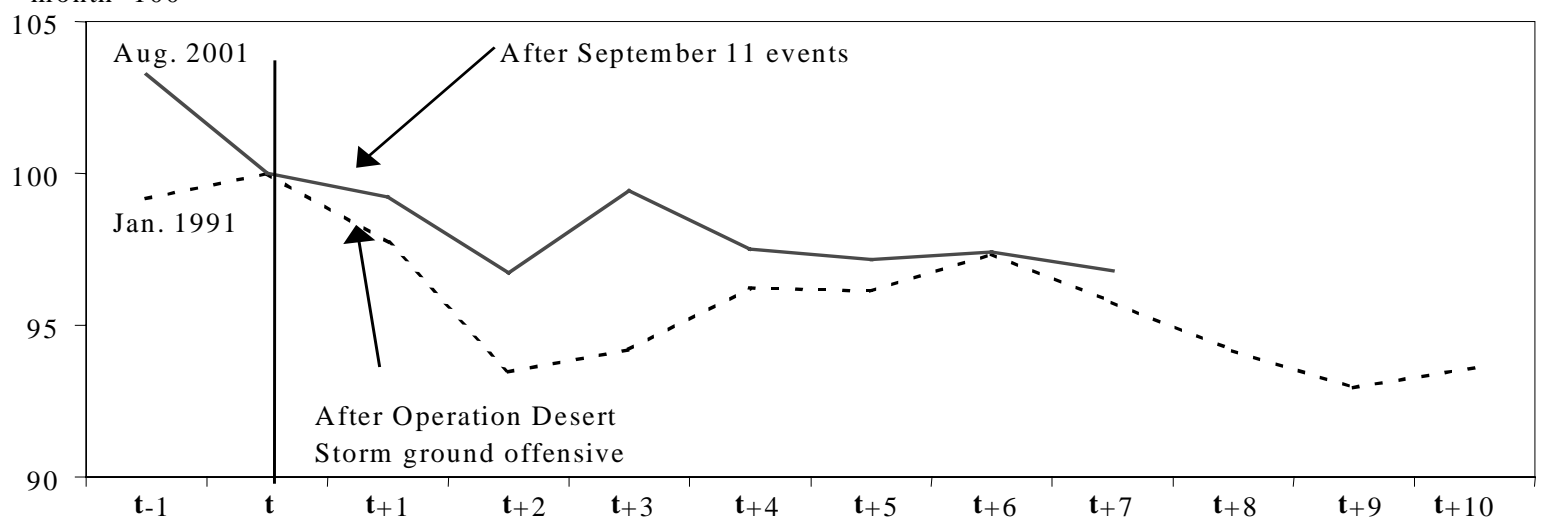

1. Monthly data refer to weighted averages of airfare CPI for the United States and Germany for the line illustrating movement following the beginning of Operation Desert Storm, and for the United States and the European Union for the line illustrating movement following the September 11 events.

Source: United States Bureau of Labour Statistics; German Statistisches Bundesamt; Eurostat. 
23. Another channel through which developments in the insurance sector may have economy-wide implications is the reduction in coverage. Uncertainty negatively affects the capital accumulation process and the existence of instruments to share and limit risk -- which help reduce uncertainty -- are often associated with increased investment. ${ }^{19}$ These instruments have included over time the creation of limited liability corporate structures, the development of hedging instruments in financial markets and the growth of the insurance industry, the size of which is positively correlated with GDP. To the extent that it increases uncertainty related to investment decisions, reduced insurance coverage may thus have a negative impact on growth.

24. The reduction in the coverage of risks is in large part the result of the difficulties insurance firms have in pricing large terrorist attacks. Until 11 September, the risk of a large magnitude event was considered low and was seldom formally incorporated into premium rates. Primary insurers and reinsurers are now facing the complex task of pricing the risks related to terrorism, which is difficult not least because it involves "correlated risk", i.e. the possibility that several catastrophic events occur simultaneously. With time, however, insurance companies will become better equipped to model "patterns" and risks of terrorist attacks, much as they already do for natural catastrophes. Indeed, a group of European insurance and reinsurance companies has recently announced their intention to set up a pool to cover against some types of terrorism risk. In the United States, airlines are in the process of creating a mutual company, Equitime, with similar purposes, although the proposed scheme has the Government act as a reinsurer of last resort. ${ }^{20}$ Finally, the use of mechanisms to transfer insurance risks to the financial markets could also play an important role in increasing coverage against terrorism. The market for insurance bonds -- sometimes known as "catastrophe bonds" -- launched in 1996, has remained thin, as the fear of information asymmetries reduced demand and the availability of cheaper sources of finance discouraged issuance by insurance companies. ${ }^{21}$ It is conceivable, however, that the increase in the industry's capital needs and ongoing efforts to repackage insurance bonds in forms more familiar to financial markets may increase liquidity and lead to a larger role for capital markets in providing alternative risk transfer mechanisms in the future. 22

25. The efficient modelling of "patterns", the building of adequate private insurance capacity and the development of risk transfer mechanisms for terrorism insurance are likely to take a few years. In the meantime, incomplete markets for sharing risk may be construed as a market failure, which could in theory justify government intervention. Indeed, several OECD governments have long had schemes in place to cover terrorism risk (Box 4). Many of those schemes were introduced to deal with a particular set of political events, which had led to a re-evaluation of risks and the reduction of coverage. Often, they were thought of as a temporary state response to market failure, in the expectation that with time, the insurance industry's capacity would develop and efficient risk-sharing arrangements would be re-established. The fact that many of these schemes have endured beyond their original mandate is an indication that either the market failure was not temporary or that government intervention crowded out private sector responses. Finally, the design of support schemes is necessarily dependent on the particularities of domestic judicial processes. For instance, the UK's Pool Re scheme, which does not provide reinsurance for liability

19. See Bassanini and Scarpetta (2001), Dixit and Pyndick (1994), Hartman (1972) and Leahy et al. (2001).

20. Several insurance or reinsurance companies, specialised either in terrorism risk insurance or in the aviation industry, have also been created in the Bermudas since the attacks.

21. Niehaus (2002). Insurance ("catastrophe") bonds are debt instruments carrying a premium reflecting the agreement by investors to forgive some of the principal and/or interest payment in case a specified catastrophe occurs.

22. See A.M. Best's Review, February 2002. Since 1996, approximately $\$ 13$ billion of insurance bonds have been issued -- a relatively small amount. 
coverage, would be less applicable in the United States, where the judicial system allows a much wider scope for litigation on third-party liability cases. These differences also complicate international pooling efforts.

\section{Box 4. State mechanisms to provide insurance or reinsurance against terrorism risk}

Several OECD countries that have experienced lasting pressures from terrorists have established government-sponsored insurance coverage schemes.

In the UK, a pool reinsurance company, Pool Re, was established in 1993 to ensure the continued availability of insurance cover for damage and loss caused by terrorist actions, which had become largely unavailable after a spate of IRA attacks. Pool Re functions as a reinsurance company for its (voluntary) members, while the Government provides reinsurance to Pool Re. The first $£ 100000$ lies with primary companies, with Pool Re intervening only above that amount. Losses from underwriting activities are covered by accumulated premia or, if needed, by an additional call on members (limited to 10 per cent of the annual premium). Beyond that, claims are met by the Government. This scheme enables insurers to cover terrorism without the need to restrict the sums insured, but does not encompass third-party liability insurance.

In Spain, the state insurance compensation fund (CCS, Consorcio de Compensación de Seguros) was created in 1928 and now covers a variety of "extraordinary" risks, including terrorism. Premia are collected through a surcharge on all policies in specific risk categories. Traditionally, CCS has provided subsidiary cover and served as a guarantor if a primary insurer is declared insolvent, so it did not technically provide reinsurance. After the 11 September attacks, however, the fund has started providing reinsurance for air transportation against war and terrorism risks (third party liability only).

In France, since December 2001, the state-owned Caisse Centrale de Réassurance under government guarantee, covers physical and property damages caused by terrorism attacks above an annual $€ 1.5$ billion ceiling. Under this amount, the insurance and reinsurance markets cover the risks. Outside the OECD area, countries that have special mechanisms to deal with terrorism risks include South Africa (where SASRIA, the South African Special Risk Insurance Association, created in 1979, insures against political risks) and Israel (where the Property Tax and Compensation Fund, financed by a nation-wide property tax, covers property and casualty insurance claims from terrorism-related losses). Several OECD countries, including Switzerland and Japan, have some type of government scheme to insure against "catastrophes", but these do not specifically include terrorism.

In the United States, following the 11 September attacks, the administration proposed a transitional threeyear "Share Loss Compensation Programme" to address the risk of a shrinkage of affordable insurance. Under the programme, which has not been approved by Congress, the share of insurers in loss compensation would have been capped (as a percentage of total losses), with government stepping in beyond that limit. The cap was to be increased gradually until 2004, when government involvement would have been phased out.

26. Overall, even though it has been hit by the largest amount of reimbursements ever recorded, the insurance industry has escaped bankruptcy, and some large reinsurers are still able to distribute dividends to their shareholders. In reaction to the terrorist attacks, commercial insurance premium rates have been raised significantly, but this partly offsets the decline recorded in the last decade. This pricing power encourages the entry of new capital in the industry, which will spur competition and help contain further rate increases. More worrying is the shrinkage of coverage for commercial properties deemed too risky and for terrorism risk altogether. The private insurance sector may eventually decide to re-enter the market for some types of terrorism-related risks, but such a prospect is at present elusive not in the least because the industry may not be in a position to face losses of a similar magnitude of that of 11 September. Hence, close monitoring is warranted. If government involvement proves justified, it should be limited in scope, be conceived in partnership with the private sector and be accompanied by the introduction of some type of user fee. In that regard, multi-pillar risk sharing mechanisms, involving insurers, reinsurers, pooling 
structures, capital markets, and possibly governments as an insurer of last resort, may offer a valid alternative. Government involvement is likely to be especially justified in the case of potential losses arising from mega-terrorism (such as a nuclear attack), which is typically excluded from standard insurance policies. In that regard, international options may also be considered.

\section{Increased shipping costs: is there a trade-off between efficiency and security?}

27. In the days following the 11 September terrorist attacks, the air transportation system was shut off for four days and the Port Authority of New York and New Jersey closed its operations for two days. More generally, the US transportation system was subject to severe disruptions largely resulting from the tightening of security measures. The most severe disruption occurred at the US-Canada land border, where on average half a million vehicles and $\$ 1.4$ billion in bilateral trade cross each day. There, beside the opportunity cost of long waits, the slowdown of border crossings had a strong impact on the operations of firms, especially in the automotive industry, where the breakdown of just-in-time supply chains led to several factory shutdowns on both sides of the border. ${ }^{23}$ As security measures were gradually lifted, and more security personnel was hired, the flow of trucks across the land borders was brought back close to normal, with the average crossing time only slightly longer than before the attacks. The signing in December 2001 of the US-Canada "smart border" initiative to facilitate trade through improved technology, co-ordination and information sharing helped in this regard. ${ }^{24}$

28. Beyond the short-term impact, tighter security requirements and a series of surcharges have also affected the cost of transporting goods by sea and air. For international sea shipments, this has included notification requirements, more frequent Coast Guard inspections and tugboat escort obligations, which have resulted in increased costs and longer waiting times. For airfreight, higher security-related costs at airports led to the application of security charges, higher commercial insurance premia and war surcharges for certain sensitive regions (Box 5).

\section{Box 5. New security measures and surcharges}

Beyond the closing down of borders, tighter security requirements and a series of surcharges have affected the cost of transporting goods in the aftermath of the attacks.

Both Canada and the US have instituted a mandatory 96-hour advance arrival notices for ships (up from 24-hour before the attacks) and more frequent onboard Coast Guard inspection of crews and cargo. Also, ships have had to travel at lower speeds inside US harbours, flanked on each side by a tugboat (escort requirements), at a cost of between $\$ 1000$ and $\$ 1500$ per ship. Notification requirements have also been tightened, with additional information required for ships arriving or departing US ports.

Higher security-related costs at airports led to the application of security charges by airlines in the range of \$0.10 to \$0.15 per kilogram of cargo in North America, Europe and Asia.

Commercial insurance premia were raised for both sea and air cargo, by between 0.03 and 0.05 per cent $a d$ valorem. Terrorism insurance became largely unavailable. War surcharges have been applied to ocean freight cargo transiting the Middle East, Red Sea, the Suez Canal and the Eastern Mediterranean. Besides neighbouring countries, this has also affected important Europe-Far East trade lanes.

23. See Andrea and Smith (2002).

24. In March 2002, a similar initiative for the US-Mexico border was unveiled. 
29. In spite of the new security requirements, six months following the attacks most available indices showed little evidence of an increase in shipping costs and some of them had declined. Maritime shipping rates increased by 5 to 10 per cent on average in the two weeks following the attack, but that rise was soon reversed. Airfreight rates, on the other hand, were about 10 per cent higher in late 2001 than before the attacks. ${ }^{25}$ Given the sharp deceleration of aggregate demand observed since 2000 and the drop in fuel costs following the attacks, ${ }^{26}$ a sharper decline in freight costs should have occurred (Figure 12). The relative resilience of freight rates, despite lower fuel costs and under-utilised shipping capacity, would tend to suggest that underlying transportation costs may have increased.

Figure 12. Transportation costs ${ }^{1}$

Cass Price Index

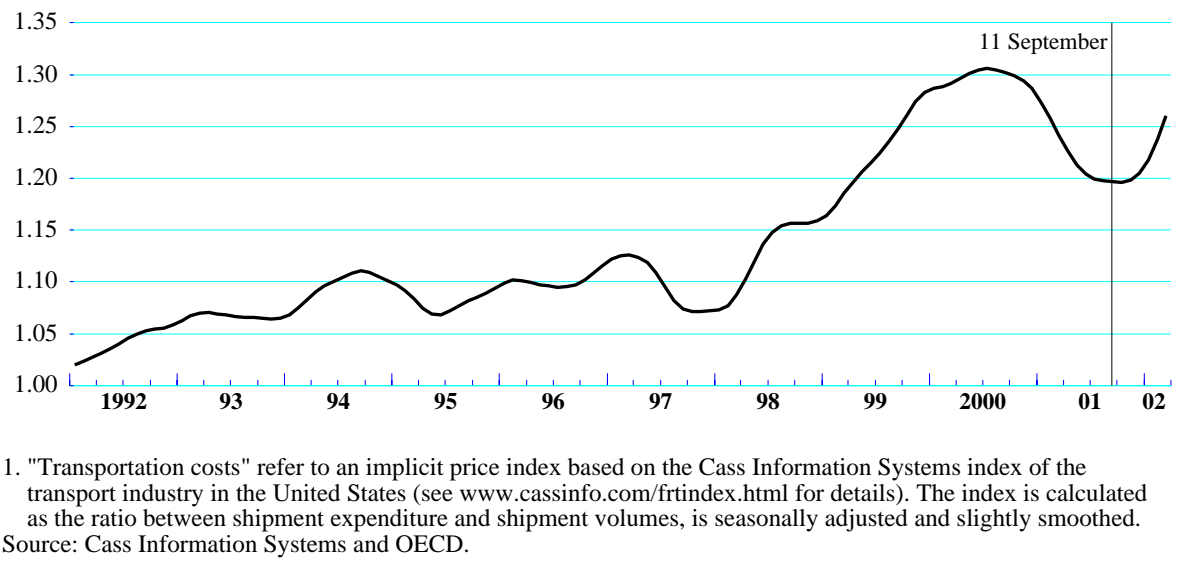

30. Even though transportation is subject to more security screening than before the attacks, especially air transport, some observers remain concerned that US borders are still too porous and that, as a consequence, the country is vulnerable to further terrorist attacks. ${ }^{27}$ Permanently tighter security measures have been advocated to make the borders less permeable. For example, the US Coast Guard has proposed to the International Maritime Organisation a series of measures for the prevention and suppression of acts of terrorism against shipping, and the US Customs Service launched an initiative to increase the security of containers, which account for some 60 per cent of the volume of world trade. Work has started in partnership with authorities responsible for 20 large ports that account for two-thirds of the containers shipped to the US. ${ }^{28}$ This involves improved procedures and technology, requiring significant capital investment in ports, ships and containers. Cargo originating in one of these ports would be able to go

25. The Bank of Japan estimates that the international air freight transportation cost index in December 2001 was 11.2 per cent higher than three months earlier. Ocean freight rates on the other hand, were down 1.2 per cent over the same period (Bank of Japan Monthly Report on the Corporate Service Price Index, December 2001).

26. According to the Air Transport Association, the average price of fuel used by the US airline industry has fallen from 92.2 cents a gallon in December 2000 to 79.6 cents in September 2001 and 60.1 cents in December 2001. Fuel costs account for between 10 and 15 per cent of total operating costs in the US airline industry -- compared with 0.3 to 0.6 per cent for insurance costs and 1.8 to 2 per cent of total operating expenses for landing fees.

27. See Flynn (2002).

28. These "megaports" include, inter alia, Bremerhaven, Genoa, Hong Kong, Kaohsiung, Pusan, Rotterdam, Shanghai, Singapore, Tokyo, and Yantian. 
through more expeditious custom procedures when entering the US, effectively zooming through a "fast lane".

31. These proposed new security requirements are likely to affect the cost of transporting goods across borders, through both higher direct costs and longer delivery times. Affordable airfreight and the decline in overall shipping costs have been important factors shaping supply chain management over the last decade. A number of industries have internationalised their supply chains and introduced just-in-time systems, most of them highly dependent on the speed and reliability of delivery provided by an efficient transportation system. This has increased opportunities for global specialisation of production and allowed a reduction in business inventories and their related carrying costs (Box 6). This greater openness to international trade has contributed to the increase in productivity levels over the last decade, and has therefore helped increase potential output. ${ }^{29}$ It has also been an important factor in spurring growth in emerging economies and combating poverty in many regions of the developing world. Reversing the trend towards higher affordability of transportation costs and tightening border crossing indiscriminately would risk scaling back openness and could have a long-lasting negative impact on growth both OECD-wide and among non-member economies.

32. Overall, industry experts have estimated soon after the attacks that the total cost of securityinspired measures could amount to between 1 and 3 per cent ad valorem (Leonard, 2001). At first glance, this range pales compared with other costs of trading internationally (Box 7). The direct impact on trading costs is, however, of a similar scale to that of the reduction in developed countries' bound tariffs on the imports of industrial goods, of 2.5 percentage points, agreed under the Uruguay Round. ${ }^{30}$ To the extent that the extra cost applies to international trade only, it will increase the cost of foreign goods compared with domestic ones. Even small differences in the cost of trading internationally, compared with domestically, may suffice to explain a strong home bias in goods spending. Thus, the trade costs associated with international transactions is found to explain a substantial portion of observed international market segmentation. ${ }^{31}$ Hence, the possibility that security measures may have a significant impact on trade flows should not be discarded. Elasticity of trade flows with respect to transaction costs are estimated to range between -2 and -3 , implying that even a relatively small increase in the costs of trading internationally in the order of 1 per cent would lead to a drop in trade flows of between 2 and 3 per cent. ${ }^{32}$

29. See Bassanini and Scarpetta (2001).

30. Although the direct impact on trading costs are of a similar scale, the welfare effect of changes in tariff rates are different, since account needs to be taken of dynamic (secondary) effects, including on government revenues. Bound tariffs on developed country imports of all industrial products were reduced from 6.3 to 3.8 per cent on average with the Uruguay Round of multilateral trade negotiations.

31. See Frankel (2000), Obstfeld and Rogoff (2001) and Parsley and Wei (2000). Obstfeld and Rogoff discuss the role of international trading costs in the existence of a strong home bias in goods spending, as well as in the holding of assets and in the financing of investment expenditures.

32. See Limão and Venables (2001). 
$\mathrm{ECO} / \mathrm{WKP}(2002) 20$

\section{Box 6. Shipping costs and supply chain management}

Land and sea-based shipping costs - including freight, handling and insurance costs -- have declined sharply over the past century and a half. This has been the result of cost-saving technological advances in shipping, which have included the development of super-tankers, roll-onroll-off ships, containers and refrigerated cargoes. In more recent decades, this decline has also been observed in the cost of airfreight. The real price per kilogram of shipping goods by air has fallen on average by about one third between 1973 and $1993 .{ }^{1}$ The ratio between airfreight prices and the value of goods transported (the ad-valorem rate) has dropped even more sharply, by about half within the same twenty years. This has resulted in a shift in the relative importance of the different modes of transportation for international trade, with the tonnes-kilometres of cargo flown world-wide increasing by a factor of 7.5 in the quarter century to 1994. By that year, a fifth of US imports and almost a third of US exports were transported by air.

The decline in shipping costs, together with the even sharper fall in communication costs and the reduction of many trade barriers, has been one of the main drivers in the process of globalisation of production and the associated sharp growth of international trade over the past few decades. At firm level, the increased affordability of airfreight and the decline in overall shipping costs have been an important factor in shaping supply chain management. Several industries have internationalised their supply chains and introduced just-in-time systems, most of them highly dependent on the speed of delivery provided by an efficient transportation system. This has increased the opportunity for a global specialisation of production and allowed a reduction in business inventories and their related carrying costs. As a result, both potential output and productivity growth have been enhanced world-wide.

The disruptions caused by the terrorist attacks have raised concerns for the future of the supply chain management model increasingly used by firms in OECD countries. After 11 September, the US authorities have tightened security compliance requirements. More careful background checks are being required for truck drivers, tugboat escort requirements in ports are more stringent, access to aircraft cargo bays has been restricted and the transport of hazardous material is more closely regulated. Insurance rates have also been raised and security surcharges added. All these security measures involve additional costs and can lead to more unpredictable transit times. Although those effects are small under present circumstances, they may be large enough to encourage industries to reconsider the reliance on just-in-time inventory management and include just-in-case buffers in their stocks. This could have an impact on the cost of carrying inventories. ${ }^{2}$

Business logistics (i.e. the management of inbound material resources and outbound products) represent a sizeable, though declining, fraction of overall production costs. Estimates by sector specialists put annual spending on business logistics in the United States at about $\$ 1$ trillion in 2000 . $^{3}$ This includes approximately $\$ 590$ billion in transportation costs, the bulk of it being accounted by truckload and airfreight services. ${ }^{4}$ The cost of carrying inventories is estimated at $\$ 380$ billion per year, which includes capital cost, management of stocks, insurance, inventory depreciation and warehousing facilities. The remainder is accounted by administrative costs.

This cost of business logistics is estimated to have fallen from 16 to 10 per cent of GDP during the last twenty years, for two main reasons. First, improved supply chain management models have made it possible for companies to operate with thinner inventories and therefore cut back on carrying costs. Indeed, some companies in the automobile or computer sectors are reported to operate with only one or two days of stocks of material inputs. Thus, the sharp fall in overall inventories, from 25 to 15 per cent of GDP in the last twenty years, presumably stems from the increased reliance on just-in-time models. Second, the cost of transportation services has dropped in relation to other producer prices since the deregulation of the early 1980s.

The terrorist attacks could encourage companies to hold larger inventories as a precaution against possible disruptions in the supply chain. It is admittedly difficult to estimate what new level of inventories businesses would be comfortable with. For illustrative purposes, raising inventories back to the level of 1990 in relation to GDP would require approximately $\$ 300$ billion in working capital. This would in turn impose an inventory carrying cost of about $\$ 75$ billion per year (0.7 per cent of GDP). Some companies have indeed announced that they would raise their level of input inventories as a precaution against the uncertainty of deliveries. The trend of private stocks should therefore be kept under monitoring, although some time will be needed to distinguish between short-term cyclical movements and structural changes.

1. Deflated by the US GDP deflator. See Hummels (1999).

2. See MIT Center for Transportation Studies (2001).

3. See Delaney and Wilson (2001).

4. Measuring the production of the transportation sector is fraught with numerous difficulties. The US Bureau of Economic Analysis and the Bureau of Transportation Studies produce Transportation Satellite Accounts attempting to assess the contribution of transportation to overall output. For 1996, the value-added of the transportation sector is estimated at $\$ 379$ billion, the equivalent of 4.8 per cent GDP, significantly less than the cost measured by sector specialists, perhaps because of differences in definitions and methodology. 


\section{Box 7. The cost of trading internationally}

In spite of the long-term decline in transportation and transaction costs, there is strong evidence that national borders and geography still impede international trade and investment. It is estimated that on average trading internationally costs 10 to 25 per cent more than trading domestically. ${ }^{1}$ This is the result of several factors, including tariffs, non-tariff barriers, currency conversion costs and differences in legal and payments systems, as well as shipping costs.

- Average tariff rates in OECD countries (on a domestic-production-weighted basis) vary between 3 and 10 per cent. Non-tariff barriers are estimated to have an effect in the same order of magnitude. ${ }^{2}$ These barriers can be significantly steeper for "sensitive" products however, including steel, textiles, footwear and agricultural products.

- The cost of border clearance, which includes the cost of collecting, producing, transmitting and processing required information and documents, can also be significant. These "compliance" costs are estimated at between 2 and 7 per cent ad valorem, but can be considerably higher in some developing countries. ${ }^{3}$ Once the cost of time delays is added, border clearance can cost between 5 and 13 per cent of the value of the traded good. ${ }^{4}$

- Shipping costs vary widely, depending inter alia on the good shipped, the origin and destination. The share of transportation and insurance costs in the custom value of goods traded by the United States has remained relatively stable at about $3 \frac{1}{2} 2$ per cent in the past few years, with insurance alone typically costing between 0.10 and 0.15 per cent ad valorem. There are wide differences however, between trade in medicinal and pharmaceutical products (classified under SITC 54) and trade in vegetables and fruits (SITC 05) - with shipping costs at respectively 1 and 15 per cent of customs value in 2000. Average costs are typically higher for other countries, with less efficient port facilities and less significant economies of scale and scope in the shipping industry.

1. See Obstfeld and Rogoff (2001).

2. See Anderson and Neary (2001).

3. See OECD (2002), Ernst \& Whinney (1987) and European Commission (1999).

4. It is estimated that each extra day of shipping time is worth on average 0.5 per cent ad valorem (Hummels, 2001).

33. Even though a trade-off between security and efficiency of border crossings cannot be fully avoided in the short-term, it is likely that this trade-off can be eliminated in the medium-term. New security measures can be formulated in a way that does not diminish the efficiency of merchandise border crossings. New regulations should for instance be subject to risk-management analyses to ensure that they address the most critical risks. The additional costs can also be minimised by a co-operative approach between the private and the public sector in both the design and implementation phases. Security measures should be introduced with a sufficiently long implementation lag and enough flexibility to allow business to find the least costly way of meeting new requirements. The air cargo security regime introduced by the United Kingdom in the wake of the Lockerbie disaster of 1988 is a good example in this regard. The global impact of security measures should also be carefully taken into account. Bilateral agreements between customs authorities to organise "fast lanes" for containers originating from secure ports appear at first glance to be an efficient solution, but they could be discriminatory, especially against developing countries (Box 8). International co-operation and consensus building would help make new security measures more efficient while reducing their potentially negative impact on trade flows. 
$\mathrm{ECO} / \mathrm{WKP}(2002) 20$

\section{Box 8 . The impact on developing countries}

The limited short-term economic impact of the attacks on advanced economies helped allay fears over the fallout on developing countries. The widening of bond spreads, the fall in commodity prices and the weakening of currencies that plagued many emerging markets soon after the attack, have been quickly, if sometimes only partly, reversed. If domestic demand recovers as expected in OECD countries, prospects for emerging markets should improve further. Over the longer-term however, the overall impact of the terrorist attacks on developing countries could be substantial. This impact could come through three main channels: shipping costs, the tourism industry and workers' remittances:

- The effect of the proposed tightening of security on the cost of trading internationally is likely to be asymmetrical. Developing country exports often have higher ad valorem transportation costs (notably bulky commodities and perishable goods transported by air) and should thus be affected disproportionately. A "certification" procedure with selected foreign ports could be discriminatory if developing country ports fail to qualify. "Know-yourpartner" initiatives, whereby pre-registered intermediaries go through simplified border procedures, may also favour large trading companies over smaller developing country-based firms. These proposed measures risk creating a "slow lane" for developing country exports, increasing relative compliance costs and eroding their competitiveness.

- Heightened fear of travelling following the attacks led to a number of cancellations and a drop in new bookings. Reservations world-wide fell by an estimated 12 to 15 per cent in October 2001 compared with the previous year, and had still not fully recovered by early 2002 according to the World Tourism Organisation. In developing countries, travel services account on average for about 7 per cent of total exports of goods and services and 2 to 3 per cent of GDP. The number is considerably higher in the Caribbean, the South Pacific and for some countries in the Middle East and North Africa region (Egypt, Jordan, Morocco and Tunisia) as well as in South and Southeast Asia (Nepal, Sri Lanka, Thailand and Vietnam). The drop in tourism traffic has also been asymmetrical, with some of the countries that depend most heavily on the industry experiencing the largest number of cancellations. Although the tourism industry is expected to recover as consumers gradually revert to a business-asusual attitude towards travelling, the increase in the perception of risk for some destinations is likely to be more permanent.

- For security reasons, visa requirements and the control of illegal immigration have started to be tightened in advanced countries. ${ }^{1}$ This has the potential to lower the number of developing country workers employed abroad, affecting the level of remittances. The fact that a disproportionate share of these emigrants work in the tourism industry (hotels especially) should also affect transfers. Emigrants' remittances are an important source of income for most of Central America, the Caribbean and South Asia, as well as for some countries in the Pacific and in Southeast Asia. Although the exact level of transfers is difficult to determine, since part of them transit through unofficial channels, emigrants' remittances are higher than exports for several countries. ${ }^{2}$

1. See Human Rights Watch (2001).

2. See Puri and Ritzema (1999).

\section{The impact of growing security and military spending: has the "peace dividend" been reversed?}

34. Immediately after the attacks, the US Administration and (to a lesser extent) other OECD governments increased public spending to help reconstruction, strengthen domestic security and combat terrorism. These additional appropriations resulted in a sharp increase of general government spending in the fourth quarter of 2001, which helped support aggregate demand and avoid a decline in domestic output. Such a temporary increase is not unusual after large catastrophes or natural disasters (Table 3) such as the Kobe earthquake or the windstorms that struck part of Europe in December 1999. 
ECO/WKP(2002)20

Table 3. Fiscal support to domestic demand in the aftermath

of selected catastrophes

saar in per cent

\begin{tabular}{|c|c|c|c|}
\hline \multirow[b]{2}{*}{ Italy } & \multirow[b]{2}{*}{ November 1980 earthquake } & \multicolumn{2}{|c|}{$\begin{array}{l}\text { Public spending in the subsequent quarter } \\
\begin{array}{c}\text { quarter-on quarter } \\
\text { change }\end{array}\end{array}$} \\
\hline & & 4.1 & 0.9 \\
\hline Spain & August 1983 flood & 3.1 & 0.5 \\
\hline United States & August 1992 hurricane Andrew & 2.1 & 0.4 \\
\hline United States $^{a}$ & January 1994 Los Angeles earthquake & 0.7 & 0.1 \\
\hline Japan $^{b}$ & January 1995 Kobe earthquake & 3.5 & 0.8 \\
\hline Turkey $^{c}$ & August 1999 earthquake & 13.1 & 1.1 \\
\hline France & December 1999 storms & 3.6 & 0.9 \\
\hline United States & 11 September 2001 attacks & 10.2 & $1.8^{d}$ \\
\hline $\begin{array}{l}\text { a) The increase } \\
\text { b) The increase } \\
\text { c) Refers to gove } \\
\text { d) Of which } 0.7 \\
\text { Source: OECD. }\end{array}$ & $\begin{array}{l}\text { next following quarter was much higher }(+8 \% \\
\text { next following quarter was much higher }(+15 \\
\text { t consumption spending only. } \\
\text { ntage points at the federal level, with half ther }\end{array}$ & eof falling under nation & al defence. \\
\hline
\end{tabular}

35. Further to this additional appropriation, the US President has requested from Congress an expansion of security-related programmes in the context of the budget for FY2003. Additional spending of $\$ 48$ billion was proposed for national defence (an increase by 14 per cent from the previous year). In addition, the President asked Congress for an appropriation of $\$ 38$ billion to boost "homeland security", compared to $\$ 20$ billion spent in 2001. This seeks to improve the preparedness of "first responders" (firemen, police, rescue workers), enhance defences against biological attacks, secure borders and improve information sharing, and includes $\$ 8$ billion for domestic defence spending. ${ }^{33}$

36. The additional spending is being financed by government borrowing. There is little indication that taxes will be raised to finance this effort. The Administration has proposed to hold back the increase in other non-discretionary spending to no more than 2 per cent in nominal terms. This would require an unprecedented degree of discipline in such spending, which might not be accepted by Congress.

37. Other OECD Member countries do not appear to have increased their security-related budgetary spending to a similar extent, but have nonetheless diverted resources within existing budgets to improve preparedness and finance counter-terrorism actions. Thus, additional resources are being devoted to the military and the police in several cases (Table 4). Canada has started to implement a five-year programme to fight terrorism, costing 0.7 per cent of GDP. Germany has approved an anti-terror package equivalent to 0.1 per cent of GDP. The armed forces in the United Kingdom have requested an additional 0.7 per cent of GDP to meet the requirements of the war against terrorism. Limited information is readily available for the time being on actions taken by other OECD countries (a better picture will emerge when draft budgets for 2003 are presented). Based on anecdotal evidence, it seems that both military and domestic security spending is set to rise, although less than in the United States.

33. In March 2002, an additional \$27 billion emergency funding request was made, involving supplemental appropriations for FY2002 (of which $\$ 19$ billion going to defence and homeland security). 
Table 4. Spending on defence and police in selected countries

\begin{tabular}{|c|c|c|c|c|c|c|c|c|c|}
\hline \multicolumn{10}{|c|}{ As a percentage of GDP } \\
\hline & \multicolumn{3}{|c|}{2000} & \multicolumn{3}{|c|}{2001} & \multicolumn{3}{|c|}{2002} \\
\hline & Defence & Police & Total & Defence & Police & Total & Defence & Police & Total \\
\hline United States $^{a}$ & 3.0 & 0.1 & 3.1 & 3.0 & 0.1 & 3.1 & 3.3 & 0.1 & 3.4 \\
\hline Japan $^{a}$ & 1.0 & 0.1 & 1.0 & 1.0 & 0.1 & 1.0 & 1.0 & 0.1 & 1.1 \\
\hline Germany $^{b}$ & .. & .. & 1.3 & .. &.. & 1.3 & .. & .. & 1.3 \\
\hline France & 2.6 & 0.3 & 3.0 & 2.6 & 0.3 & 2.9 & 2.5 & 0.3 & 2.8 \\
\hline Italy $^{c}$ & 1.1 & 1.5 & 2.6 & 1.2 & 1.5 & 2.8 & 1.3 & 1.6 & 2.8 \\
\hline United Kingdom $^{a}$ & 1.9 & 0.8 & 2.7 & 1.9 & 0.9 & 2.7 & 1.8 & 0.9 & 2.7 \\
\hline Canada $^{a}$ & .. & .. & 1.3 & .. & .. & 1.5 & .. & .. & 1.5 \\
\hline \multicolumn{10}{|c|}{$\begin{array}{l}\text { Note: Figures in this table are based on national budgets (and not on national accounts) and are therefore not } \\
\text { strictly comparable across countries. }\end{array}$} \\
\hline \multicolumn{10}{|c|}{$\begin{array}{l}\text { a) Fiscal year basis, federal (or central) government only. } \\
\text { b) Includes an anti-terrorism package equivalent to } 0.07 \text { per cent of GDP in } 2002 \text { which is budgeted as a separate } \\
\text { item from defence and public order. There is a break in functional budget definitions between } 2000 \text { and } 2001 \\
\text { for defence. } \\
\text { c) State sector (central government). } \\
\text { Source: National budgets. }\end{array}$} \\
\hline
\end{tabular}

38. The recent rise in security spending started from a relatively low initial level, as most NATO countries had reduced military spending since the 1980s. In the United States, defence spending dropped to 3 per cent of GDP in 2000, well below the peak of over 6 per cent of GDP at the climax of the Cold War build-up in the mid-1980s. The proposed increase of national defence and homeland security outlays in the United States would keep spending below 4 per cent of GDP, i.e. below the levels recorded until the mid1990s (Figure 13). The increase in military spending actually started before the recent terrorist attacks. World military expenditure ${ }^{34}$ reached a low point in 1998 and increased subsequently. ${ }^{35}$ All of this suggests that the era of the so-called "peace dividend" is winding down and that OECD economies have entered a new era of increased spending on military operations and domestic security. If previous periods of military build-ups are used to draw a parallel, such increases in public spending could undermine the trend of fiscal consolidation.

39. The impact of military spending on economic growth has been the topic of theoretical and empirical research, as the "peace dividend" associated with the end of the Cold War was expected to result in positive welfare gains. Analyses suggest that military spending affects medium-term growth negatively through several channels (such as lower capital accumulation, reduced civilian labour force, losses resulting from capital reallocation). Empirical studies have, however, produced ambiguous results. ${ }^{36}$ Econometric studies typically have difficulties identifying the impact of military spending on growth because such spending boosts growth in the short-run, even though it may lower it after a lag. Although Knight et al. (1996) find a significant negative impact of military spending on growth using panel data estimation, more recent work by Smith and Dunne (2001) find no strong relations between military expenditure and either investment or growth. Overall, the conventional wisdom is that military build-ups are likely to have a detrimental long-term impact on economic growth, but this impact is likely to be small, and in any case much smaller than other traditional determinants of growth. Smith and Dunne (2001) for

34. There are several widely known databases on military spending: data compiled by the Stockholm International Peace Research Institute (SIPRI) are considered to be the best for the purpose of economic analysis because they apply a consistent definition of expenditure across countries; other publicly available international databases are kept by the NATO and the IMF.

35. See SIPRI (2002).

36. See Knight et al. (1996), Ramey and Shapiro (1998) and Smith and Dunne (2001). 
instance calculate that, based on commonly accepted parameters, an increase in military spending by one percentage point of GDP is likely to reduce potential output growth by 0.25 per cent during a transition period.

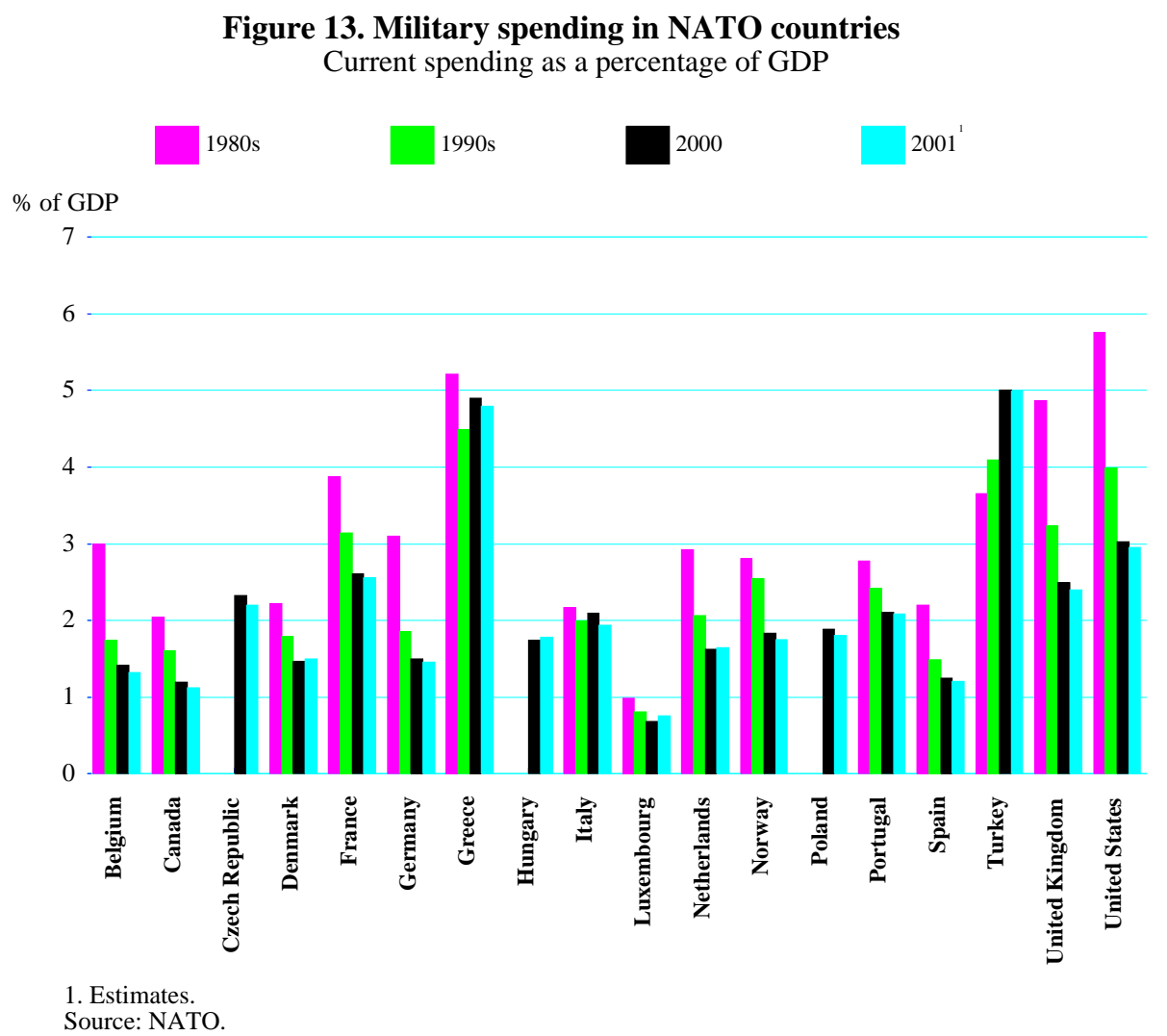

40. In addition to the rise in public spending, it is likely that private sector spending on security is rising as well. Limited data are available on private security spending, but a study by Anderson (1999) evaluates it at $\$ 40$ billion annually in the United States. Nearly half of the total spending for security by the private sector is composed of a single category, security guards and other protective service employees. The rest of the spending falls into such categories as alarms systems, computer security, locks and safes, fencing, surveillance cameras, safety lighting and guard dogs. This considerable amount is comparable to what is spent on Federal, State and local police, excluding the armed forces. Higher private spending on security would involve hiring more labour, such as ICT experts and security guards protecting commercial premises, and would therefore reduce the level of labour productivity. Like pollution-reducing spending, private efforts to enhance security improves welfare, but does not produce output the way it is traditionally measured. Other security measures, such as time-consuming controls at airports and borders, would also lead to a lower level of productivity. The medium-term impact of a sharp increase in private security spending is, however, generally gauged to be small. A doubling of private security spending would reduce 
the level of potential output by 0.6 per cent after five years ${ }^{37}$ and the level of private sector productivity by at most 0.8 per cent. ${ }^{38}$

41. The increase in public and private sector spending on domestic security and the armed forces, even though it does not reverse the peace dividend, cannot be considered as entirely negligible. To calibrate the possible economic impact, the US block of OECD's Interlink model was used to simulate a permanent increase of military spending by 1 per cent of GDP and of government employment by 0.5 per cent of the labour force, spread between 2001 and 2003 and financed by government borrowing. Private spending on security is assumed to increase permanently by 0.5 per cent of GDP. The short-term boost on aggregate demand would increase output above the baseline level during three years. Afterwards, however, higher real long-term interest rates, assumed to exceed the baseline by 30 basis points, would weigh on capital accumulation. The level of labour productivity would be reduced by 0.5 per cent over three years and the real exchange rate would appreciate by about 3 per cent. Hence, starting in the fourth year, output would start falling below the baseline level. ${ }^{39}$ After five years, real GDP would be reduced by about 0.7 per cent compared to the baseline. The lesson of this simulation is that public expenditure restraint needs to be exercised, so that high public borrowing does not undermine potential growth and labour productivity is not unduly reduced. ${ }^{40}$

\section{In sum}

42. Overall, even though the short-term recovery from the terrorist attacks has been faster than expected, negative medium-term consequences through various indirect channels cannot be excluded. As noted, the rise in security-related public and private spending is likely to have a small, permanent negative effect on production factors and the level of productivity. The shrinkage of terrorism-related insurance coverage may have a detrimental impact on investment, as lenders become wary of greater potential risks, although there is no strong evidence yet of such a pattern. The international trade system is dangerously exposed, with potentially large repercussions for supply-chain management. Another devastating terrorist attack would exacerbate these trends. In sum, close attention needs to be paid to the medium-term consequences of terrorism, and measures to reduce the risk and the economic consequences of further attacks should be both security-effective and growth-friendly.

37. US Council of Economic Advisors (2002).

38. See Hobijn (2002).

39. The decline in welfare from heightened security risks is likely to exceed this figure. This cannot be easily captured by this type of exercise, however.

40. See Baily (2001). 


\section{BIBLIOGRAPHY}

ABADIE, A. and J. GARDEAZABAL (2001), "The economic costs of conflict: a case-control study for the Basque country”, NBER Working Paper, No. 8478.

ALLISON, G. (2001), “Could worse be yet to come?", The Economist, 1 November.

ANDERSON, D. (1999), “The aggregate burden of crime", Journal of Law and Economics, Vol. 42, No. 2.

ANDERSON, J. and J. NEARY (2001), "The mercantilist index of trade policy", mimeo, Boston University and University College, Dublin, July.

ANDREA, D. and B. SMITH (2002), "The Canada-US border: an automotive case study", Center for Automation Research, Ann Arbor, Michigan, January.

BAILY, M. (2001), "Economic policy following the terrorist attacks", International Economic Policy Briefs, Institute for International Economics, October.

BASSANINI, A. and S. SCARPETTA (2001), "The driving forces of economic growth: panel data evidence for the OECD countries", OECD Economic Studies, No. 33, 2001/2.

BUFFETT, W. (2002), "Letter to the shareholders of Berkshire Hathaway Inc.”, 28 February.

CUMMING, C. (2002), "September 11 and the U.S. payment system", Finance and Development, Vol. 39, No. 1.

CUMMINS, J., N. DOHERTY and A. LO (2002), "Can insurers pay for the 'big one'? Measuring the capacity of the insurance market to respond to catastrophic losses", Journal of Banking and Finance, Vol. 26, No. 2-3.

DIXIT, A. and R. PYNDICK (1994), Investment under Uncertainty, Princeton: Princeton University Press.

DELANEY, R. and WILSON, R. (2001), "Managing logistics in a perfect storm", Presentation of the $12^{\text {th }}$ annual State of Logistics Report, National Press Club, Washington DC.

DRAKOS, K. and A. KUTAN (2001), "Regional effects of terrorism on tourism: evidence from three Mediterranean countries", Zentrum für Europäische Integrationsforschung Working Paper, No.B26.

DRI-WEFA (2002), Financial Impact of World Trade Center Attack, Prepared for the New York State Senate Finance Committee, January.

ERNST \& WHINNEY (1987), "The cost of 'Non-Europe': border related controls and administrative formalities", in: Research on the Cost of 'Non-Europe' -- Basic Findings, Vol. 1 (Commission of the European Communities). 
EUROPEAN COMMISSION (1999), "Trade facilitation in relation to development", submission of the European Communities to the World Trade Organisation, G/C/W/143 and WT/COMTD/W/60.

FERGUSON, R. (2002), “A supervisory perspective on disaster recovery and business continuity", Remarks delivered before the Institute of International Bankers, 4 March, Washington, DC.

FLYNN, S. (2002), “America the vulnerable”, Foreign Affairs, Vol. 81, No. 1.

FRANKEL, J. (2000), "Globalization of the economy", in Governance in a Globalizing World, J. Nye and J. Donahue (eds.), Brookings Institution Press, Washington, DC.

GENERAL ACCOUNTING OFFICE (2000), Information Security: Serious and Widespread Weaknesses Persist at Federal Agencies, GAO/AIMD-00-295, Washington DC, September.

GENERAL ACCOUNTING OFFICE (2002), Terrorism Insurance: Rising Uninsured Exposure to Attacks Heightens Potential Economic Vulnerabilities, GAO-02-472T, Washington, DC.

GLAESER, E. and J. SHAPIRO (2001), "Cities and warfare: the impact of terrorism on urban form", NBER Working Paper, No. 8696.

HARTMAN, R. (1972), "The effects of price and cost uncertainty on investment", Journal of Economic Theory, Vol. 5, No. 2.

HOBIJN, B. (2002), “What will homeland security cost?”, Federal Reserve Bank of New York, mimeo, February. Forthcoming in a special issue of Economic Policy Review.

HUMAN RIGHTS WATCH (2001), "No safe refuge: the impact of the September 11 attacks on refugees, asylum seekers and migrants in the Afghanistan region and worldwide", Human Rights Watch Backgrounder, October 18.

HUMMELS, D. (1999), "Have international transportation costs declined", mimeo, University of Chicago.

HUMMELS, D. (2001), “Time as a trade barrier”, mimeo, Purdue University, July.

KNIGHT, F. (1921), Risk, Uncertainty and Profit, Boston and New York, Houghton Mifflin Co., The Riverside Press.

KNIGHT, M., N. LOAYZA, and D. VILLANUEVA (1996), "The peace dividend: military spending cuts and economic growth", IMF Staff Papers, Vol. 43, No. 1.

KUMAR, M. and A. PERSAUD (2001), "Pure contagion and investors' shifting risk appetite: analytical issues and empirical evidence", IMF Working Paper, No. 01/134.

LAKE, A. (2000), 6 Nightmares, New York, Little, Brown and Company.

LAQUEUR, W. (1996), "Postmodern terrorism: new rules for an old game", Foreign Affairs, September/October.

LEAHY, M., S. SCHICH, G. WEHINGER, F. PELGRIN and T. THORGEIRSSON (2001), "Contributions of financial systems to growth in OECD countries", OECD Economics Department Working Papers, No. 280, Paris. 
LEONARD, J. (2001), Impact of the September 11, 2001 Terrorist Attacks on North American Trade Flows, Manufacturers Alliance/MAPI e-Alerts, October, Arlington, Virginia.

LIMAO, N. and A. VENABLES (2001), "Infrastructure, geographical disadvantage, transport costs and trade”, World Bank Economic Review, Vol. 15, No. 3.

MIT CENTER FOR TRANSPORTATION STUDIES (2001), "Global terrorism and its impact on supply chain management", Audio Conference (http://web.mit.edu/cts/www/news/current/terrorism.htm\#jitua).

NIEHAUS, G. (2002), "The allocation of catastrophe risk", Journal of Banking and Finance, Vol. 26, No. 2-3.

OBSTFELD, M. and K. ROGOFF (2001), “The six major puzzles in international macroeconomics: is there a common cause?", NBER Macroeconomics Annual 2000, MIT Press.

OECD (2002), "The impact of the terrorist attacks of 11 September 2001 on international trading and transport activities", Working Party of the Trade Committee, March, TD/TC/WP(2002)9/FINAL.

PARSLEY, D. and J. WEI (2000), "Explaining the border effect: The role of exchange rate variability, shipping costs, and geography", NBER Working Paper, No. 7836.

PURI, S. and T. RITZEMA (1999), "Migrant worker remittances, micro-finance and the informal economy: prospects and issues", International Labour Organization Social Finance Unit Working Paper, No. 21.

RAMEY, V. and M. SHAPIRO (1998), "Costly capital reallocation and the effects of government spending", Carnegie-Rochester Conference Series on Public Policy, Vol. 48, No. 1.

REICH, W. (ed) (1998), Origins of Terrorism: Psychologies, Ideologies, Theologies, States of Mind, Woodrow Wilson Center Press.

SIPRI (2002), Recent Trends in Military Expenditure, www.sipri.org

SMITH, R. and P. DUNNE (2001), "Military expenditure growth and investment", mimeo, Birbeck College and Middlesex University Business School, April.

STERN, J. (1999), The Ultimate Terrorists, Cambridge, Harvard University Press.

UNITED NATIONS CONFERENCE ON TRADE AND DEVELOPMENT (2001), "Transnational corporations expected to continue worldwide expansion, but full impact of economic slowdown still unknown: highlights of a corporate investment survey", Note to correspondents, TAD/INF/NC27, 5 December 2001.

US COUNCIL OF ECONOMIC ADVISORS (2002), Economic Report of the President, Washington DC. 


\section{ANNEX 1. CYBER-TERRORISM}

Governments and private agents across the world increasingly rely on interconnected computer systems. At the same time, the number of individuals with computer skills is rising and intrusion ("hacking") techniques have become readily accessible. There is also evidence that some terrorists groups have been acquiring rudimentary cyber-attack tools. The number of cyber-incidents has soared: those notified to the Carnegie-Mellon University's Computer Emergency Response Team rose from 252 in 1990 to over 52000 in 2001, and they are estimated to represent only about one fifth of actual occurrences. Cyber-attacks can entail considerable economic costs, as has been the case for some "viruses" (Table A1.1).

Table A1.1. Estimated worldwide economic impact of malicious code attacks In billions of US dollars

\begin{tabular}{|c|c|c|c|c|}
\hline \multicolumn{2}{|c|}{ Annual estimates } & \multicolumn{3}{|c|}{ Selected incidents } \\
\hline 1995 & 0.5 & 1999 & Explorer & 1.02 \\
\hline 1996 & 1.8 & & Melissa & 1.10 \\
\hline 1997 & 3.3 & & & \\
\hline 1998 & 6.1 & 2000 & Love & 8.75 \\
\hline 1999 & 12.1 & & & \\
\hline 2000 & 17.1 & 2001 & SirCam & 1.15 \\
\hline 2001 & 13.2 & & Code Red & 2.62 \\
\hline & & & Nimda & 0.64 \\
\hline
\end{tabular}

Source: Computer Economics

So far, cyber-aggressions have generally involved fraud, theft, sabotage, vandalism or extortion rather than terrorism. Nonetheless, there is a clear risk that they be used to amplify the impact of a physical attack, for example by jamming emergency telephone numbers or shutting down electricity or telecommunications after blowing up a building or releasing toxic gases. In addition, the scope for such terrorism is likely to increase as the real and virtual worlds become more closely coupled, with automobiles, appliances, and other devices increasingly attached to the Internet. While steps have been taken by governments and enterprises to protect their systems, information security weaknesses remain widespread. ${ }^{1}$ Efforts to protect critical infrastructures from devastating computer-based attacks by terrorists (or hostile nation states) are similar to and need to be integrated with other computer security activities.

\footnotetext{
${ }^{1}$ This has been documented by the General Accounting Office (2000) for federal agencies in the United States.
} 


\section{ANNEX 2. REINFORCING AIRLINE SECURITY IN THE UNITED STATES}

The 11 September attacks highlighted that the airline security standards in the United States were rather lax compared with those prevailing in many foreign countries and prompted a number of significant changes. The Aviation and Transportation Security Act, which was signed into law on 19 November:

- Created a new Transportation Security Administration (TSA) within the Department of Transportation, responsible for the security of all modes of transportation, including aviation, rail, bus, and commercial shipping, as well as ports.

- Requires that all checked bags be screened for bombs and explosives (previously, only a fraction were screened by bomb detection systems).

- Requires that within one year, all security at US airports be handled by federal employees and that all screeners be English-speaking US citizens having passed stringent background checks. Better training and pay are expected to improve the motivation and performance of security personnel.

- Provided for a new system allowing passenger names to be checked against law enforcement watch lists to identify potential terrorists.

- Called for an increase in the number of sky marshals aboard planes, fortified cockpit doors that must remain locked during flights, and mandatory training for flight crews about how to handle a hijacking.

Additional aviation safeguards have been introduced, including restricting carry-on luggage to one bag and one personal item, allowing only ticketed passengers access to gates, banning knives and box cutters, randomly screening passengers and their carry-on luggage at the gates, limiting curbside check-in, and prohibiting passenger movements in the cabin on some flights. Passengers are now asked to arrive at least two hours ahead of time. Moreover, armed US troops and members of the National Guard patrol airports.

The direct costs of these new security measures are substantial. The FY2003 Budget provides $\$ 4.8$ billion in funding for the TSA in its first full year of operations, with an estimated $\$ 2.2$ billion to be raised through passenger and air carrier fees. These resources are to fund the well over 30000 federalised airport security staff, a greatly expanded Federal Air Marshal programme, and explosive detection systems that must be in place to screen all checked luggage by the end of 2002.

At the time of writing, the TSA is still in the process of hiring, conducting background checks on prospective workers and training them. Hiring a sufficient number of screeners and installing enough explosive detection machines to check all the luggage and keep waiting times to no more than 10 minutes, as originally intended, might be impossible within the original timetable.

1. A new $\$ 2.50$ security fee is paid by passengers for each flight segment, up to a maximum of $\$ 10$ per round trip. A proposal has been tabled by some members of the House Appropriations Committee to double this fee. 


\section{ECONOMICS DEPARTMENT \\ WORKING PAPERS}

333. Investment in human capital through post-compulsory education and training: Selected efficiency and equity aspects

(July 2002) Sveinbjörn Blöndal, Simon Field and Nathalie Girouard

332. Enhancing the Effectiveness of Public Spending in Switzerland

(June 2002) Isabelle Joumard and Claude Giorno

331. Competition and Efficiency in Publicly Funded Services

(June 2002) Jens Lundsgaard

330. Policy Pre-Commitment and Institutional Design: A Synthetic Indicator Applied to Currency Boards (May 2002) Marie-Thérèse Camilleri Gilson

329. The Role of Policy and Institutions for Productivity and Firm Dynamics: Evidence from Micro and Industry Data (April 2002) Stefano Scarpetta, Philip Hemmings, Thierry Tressel and Jaejoon Woo

328. Improving the Efficiency and Sustainability of Public Expenditure in the Czech Republic (April 2002) Andrew Burns and Kwang-Yeol Yoo

327. Increases in Business Investment Rates in OECD Countries in the 1990s: How much can be explained by fundamentals?

(April 2002) Florian Pelgrin, Sebastian Schich and Alain de Serres

326. Sectoral Shifts in Europe and the United States: How They Affect Aggregate Labour Shares and the Properties of Wage Equations

(April 2002) Alain de Serres, Stefano Scarpetta and Catherine de la Maisonneuve

325. Coping with Population Ageing in the Netherlands

(March 2002) David Carey

324. Public Spending in Italy: Policies to Enhance its Effectiveness

(March 2002) Alexandra Bibbee and Alessandro Goglio

323. Overheating in Small Euro Area Economies : Should Fiscal Policy React?

(March 2002) Peter Hoeller, Claude Giorno and Christine de la Maisonneuve

322. Encouraging Environmentally Sustainable Growth in Austria

(February 2002) Jens Høj and Andreas Wörgötter

321. Health Care Reform in Japan

(February 2002) Yutaka Imai

320. Enhancing Expenditure Control with a Decentralised Public Sector in Denmark (February 2002) Steen Daugaard

319. Options for Reforming the Finnish Tax System (February 2002) Isabelle Joumard and Wim Suyker

318. Product Market Regulation and Wage Premia in Europe and North America: An Empirical Investigation (January 2002) Sébastien Jean and Giuseppe Nicoletti 
317. Competition, Innovation and Productivity Growth: A Review of Theory and Evidence (January 2002) Sanghoon Ahn

316. Labour Market Institutions, Product Market Regulation, and Innovation : Cross Country Evidence (January 2002) Andrea Bassanini and Ekkehard Ernst

315. Ongoing Changes in the Business Cycle - Evidence and Causes (January 2002) Thomas Dalsgaard, Jorgen Elmeskov and Cyn-Young Park

314. Comment encourager une croissance ecologiquement durable en France? (December 2001) Ann Vourc'h et Patrick Lenain

313. Increasing Efficiency and Reducing Complexity in the Tax System in the United States (December 2001) Richard Herd and Chiara Bronchi

312. Product and Labour Markets Interactions in OECD Countries (December 2001) Giuseppe Nicoletti, Andrea Bassanini, Ekkehard Ernst, Sébastien Jean, Paulo Santiago and Paul Swaim

311. Modelling Import Responsiveness for OECD Manufactures Trade (October 2001) Mara Meacci and David Turner

310. Trade Linkages and the Trade Matrices in the OECD Interlink Model (October 2001) Laurence Le Fouler, Wim Suyker and Dave Turner

309. Encouraging Environmentally Sustainable Growth in Australia (October 2001) Ann Vourc'h and Robert Price

308. Financial Market Liberalisation, Wealth and Consumption (September 2001) Laurence Boone, Nathalie Girouard and Isabelle Wanner

307. The Economic Integration of Germany's New Länder (September 2001) Eckhard Wurzel

306. Standard Shocks in the OECD Interlink Model (September 2001) Thomas Dalsgaard, Christophe André and Pete Richardson

305. Fiscal Implications of Ageing: Projections of Age-related Spending (September 2001) Thai Thanh Dang, Pablo Antolin and Howard Oxley

304. The Width of the Intra-European Economic Borders (August 2001) Alain de Serres, Peter Hoeller and Christine de la Maisonneuve

303. Surveillance of Tax Policies: A Synthesis of Findings in Economic Surveys (July 2001) Paul van den Noord and Christopher Heady

302. Reforming the Tax System in Portugal (July 2001) Chiara Bronchi, José C. Gomes-Santos

301. Tax Systems in European Union Countries (June 2001) Isabelle Joumard

300. Encouraging Environmentally Sustainable Growth in Belgium (June 2001) Paul O’Brien, David Carey, Jens Høj, Andreas Woergoetter 